Revue d'archéologie préhistorique

\title{
A technological analysis of non-flaked stone tools in Olduvai Beds I \& II. Stressing the relevance of percussion activities in the African Lower Pleistocene
}

Analyse technologique des outils lithiques non taillés des Bed I et II. Mise en évidence de l'importance des activités de percussion dans le Pléistocène inférieur africain.

Ignacio de la Torre and Rafael Mora

\section{(2) OpenEdition}

\section{Journals}

Electronic version

URL: http://journals.openedition.org/paleo/1877

DOI: $10.4000 /$ paleo. 1877

ISSN: 2101-0420

Publisher

SAMRA

\section{Printed version}

Number of pages: 13-34

ISSN: 1145-3370

\section{Electronic reference}

Ignacio de la Torre and Rafael Mora, «A technological analysis of non-flaked stone tools in Olduvai Beds I \& II. Stressing the relevance of percussion activities in the African Lower Pleistocene », PALEO [Online], Numéro spécial | 2009-2010, Online since 23 April 2012, connection on 07 July 2020. URL http://journals.openedition.org/paleo/1877 ; DOI : https://doi.org/10.4000/paleo.1877

\section{cc) (†) $\ominus$}

PALEO est mis à disposition selon les termes de la licence Creative Commons Attribution - Pas d'Utilisation Commerciale - Pas de Modification 4.0 International. 


\title{
A TECHNOLOGICAL ANALYSIS OF NON-FLAKED STONE TOOLS IN OLDUVAI BEDS I \& II. STRESSING THE RELEVANCE OF PERCUSSION ACTIVITIES IN THE AFRICAN LOWER PLEISTOCENE
}

\author{
Ignacio de la TORRE ${ }^{(1)}$ et Rafael MORA ${ }^{(2)}$
}

\begin{abstract}
This paper studies the percussive technology in some of the Olduvai Bed I and II sites excavated by Mary Leakey in the 1960s. Types of percussion recorded at Olduvai and the most relevant features of the anvils, hammerstones and by-products are systematized. The importance of percussion activities versus knapping processes in some of the Olduvai assemblages is discussed, which provides insights on the functionality of early archaeological sites.
\end{abstract}

Key-words: Oldowan, Acheulean, Plio-Pleistocene, percussion tools, Olduvai, Africa.

Résumé : Analyse technologique des outils lithiques non taillés des Bed l et ll. Mise en évidence de l'importance des activités de percussion dans le Pléistocène inférieur africain. Dans cette contribution, les activités de percussion des sites des Beds I et II d Olduvai sont réexaminées à partir de l'étude des assemblages recueillis par Mary Leakey dans les années 1960. Tant les types de percussion reconnus à Olduvai que les caractéristiques principales des enclumes, des percuteurs et des produits obtenus ont été systématisés. II est ainsi possible d évaluer I importance des activités de percussion par rapport aux opérations de taille dans certains assemblages, ce qui fournit des informations significatives concernant la fonction des sites en question.

Mots-clés: Oldowayen, Acheuléen, Plio-Pleistocène, outils de percussion, Olduvai, Afrique.

\section{INTRODUCTION}

Mary Leakey (1971) divided the Olduvai Bed I \& II lithic assemblages into four main categories: tools, utilised material, débitage and unmodified items (the so-called manuports). In the tools group, Leakey (1971) included all objects she considered as standardised morphologies. Together with the débitage, they would reflect products of intentional knapping. On the other hand, the utilized materials group encompassed all the items that presented hominin modifications not necessarily related to knapping, but to the direct use of natural rocks.

Subsequent classifications of Oldowan assemblages (for example Toth 1982; Isaac 1986; Isaac et al. 1997) supported a similar division, differentiating flaked pieces (cores and retouched tools), detached pieces (flakes and flake frag- ments), pounded items and unmodified stones. These authors attempted to abandon Leakey's terminology as regards the existence of tools, utilized material and débitage, since her categories have functional implications that do not necessarily correspond to what genuinely appears in the assemblages (Isaac et al. 1997). Isaac and his colleagues aimed to use more neutral language, free of functional connotations, although when analysing individual objects they still used formal / morphological definitions of tool types (choppers, spheroids, heavy duty scrapers, etc).

In the context of this table ronde "Entre le marteau et lenclume," and in order to describe technological strategies different from the classic direct hard-hammer percussion, we focus on the utilised materials (Leakey 1971) or pounded pieces (Isaac et al. 1997) from several Olduvai Bed I and II sites. Leakey herself (1971) already empha-

(1) Institute of Archaeology, University College London, 31-34 Gordon Square, London, WC1H-OPY. United Kingdom i.torre@ucl.ac.uk.

(2) CEPAP-UAB, Edifici B5 parell - 08193 Cerdanyola del Vallès, Barcelona, Spain. 
sised the relevance of these items in the Olduvai assemblages, and our revision suggests that lithic percussion processes, not always related to knapping activities, may even be dominant in some of the sites.

This paper is based on the review of some of the assemblages excavated by Mary Leakey (1971) in Olduvai between 1960 and 1963 - FLK Zinj, DK and FLK North in Bed I, and FC West, TK Lower \& Upper Floor, EF-HR and BK in Bed II - which are curated in the National Museum of Kenya in Nairobi (tabl. 1). Our reanalysis of the Olduvai assemblages has showed certain contradictions as regards Leakey's original classification (Mora \& de la Torre 2005). Therefore, and given the relevance percussion activities had in the Bed I \& II sites, an alternative classification system for pounded pieces is presented. Such classification constitutes the basis of this paper, although its aim is not to create a new static typology that gratuitously multiplies the existing terms: instead, the main goal is to reconstruct dynamic technical processes via the proposal of analytical terms which describe stone tools used during percussion activities.

\section{The classification of percussion tools in the African Stone Age}

Regular knapping activities require the use of a hammer (be it hard or soft, direct or indirect, etc) that hits another item in order to modify its morphology and / or obtain a product. It has been proposed that the hammerstone is the key piece to distinguish between the way humans and other animals use tools, since only the former consider the hammerstone as an intermediary tool used to obtain another artefact (the flake), whilst in ethologic contexts, the hammerstone is used directly for individual tasks -to break a nut, an egg, etc. (Texier 1996).

Using hammerstones as intermediate elements in the making or modification of other artefacts can be carried out by different techniques. Apart from the most common direct hard-hammer percussion, bipolar, anvil and throwing techniques were also applied in the African Oldowan and Acheulean. The use of the bipolar technique has been proposed for the knapping of Oldowan small cores in Senga (Harris et al. 1987), Sterkfontein (Kuman 1998) and Omo (Merrick 1976; Chavaillon 1976), whilst the use of anvils for the flaking of large blanks is widely known in the Saharan (i.e. Alimen 1963) and Eastern African Acheulean (i.e. Chavaillon \& Chavaillon 1981; Jones 1994; Toth 2001; Kleindienst \& Keller 1976).

Leakey's (1971) classification places percussion tools in the utilised material category as anvils, hammerstones and cobblestones, nodules and blocks. These were characterised as lacking artificial shaping but showing some evidence of utilisation, such as chipping, blunting of the edges, smashing and battering. According to Leakey, classic hammerstones were water-worn cobblestones with pitting, bruising and shattering. She considered as anvils some pieces with cones of percussion and bruising on the upper and lower faces. Leakey divided anvils into those from the Oldowan, which she described as right-angled natural cuboid blocks with battered sides including plunging scars, and those from the Developed Oldowan, which included pieces that were shaped before their use.

\begin{tabular}{|c|l|l|l|}
\hline \multirow{2}{*}{ Bed II } & Upper & Tuff IID & $\begin{array}{l}\text { BK } \\
\text { TK }\end{array}$ \\
& & Tuff IIC & FC West \\
& & Tuff IIB & EF-HR \\
\cline { 2 - 5 } & Lower & Tuff IIA & FLK North Sandy Conglom. \\
\hline \multirow{2}{*}{$\begin{array}{c}\text { Bed I } \\
\text { (Upper } \\
\text { Member }\end{array}$} & Middle & Tuff 1F & FLK North Deinotherium L. \\
\cline { 2 - 5 } & Lower & Tuff 1D & FLK North Levels 6-1 \\
\cline { 2 - 5 } & & FLK Zinjanthropus \\
\hline
\end{tabular}

Table 1 Stratigraphic position of Olduvai sites studied in this paper, according to Leakey (1971).

Tableau 1 - Position stratigraphique des sites d'Olduvai étudiés dans cet article, d'après Leakey (1971). 
Subsequent classification systems followed Leakey (1971), while introducing some variations. Isaac et al (1997) included the types Leakey had already considered (anvils, hammerstones, modified battered cobbles) in the pounded pieces category, and added the spheroids and subspheroids. According to Leakey (1971), spheroids and subspheroids were intentionally shaped, but Isaac and his collaborators believed they were simple hammerstones. Clark \& Kleindienst (2001) followed this latter assertion, including spheroids and subspheroids in the pounded group rather than knapped materials, therefore modifying their own previous classifications of spheroids and subspheroids as heavy-duty tools (see Clark \& Kleindienst 1974).

At Melka Kunturé, percussion materials are said to reach high percentages in the Oldowan and early Acheulean. Chavaillon (1979) differentiates two main groups; one is composed by battered cobbles and hammerstones, and another by fractured cobbles. Chavaillon (1979) subdivided the hammerstones and battered cobbles group into active hammerstones (which generally have a regular, oval or rounded shape) and passive hammerstones. The passive or fixed hammerstones could be of two types: 1) small hand-held hammerstones, and 2) anvils, characterised by large size and weight, with a stable base and heavy battering on their upper faces and ridges.

Despite some differences in each classification system, all the typologies mentioned above coincide in distinguishing two main groups among the percussion material, i.e. active (classic hammerstones) and passive hammers (anvils). Although at Koobi Fora anvils or spheroids are absent or appear incidentally (Isaac et al. 1997), in the Olduvai sequence (Leakey 1971; Leakey \& Roe 1994) and at Melka Kunturé (Chavaillon 1979; Chavaillon \& Chavaillon 1976, 1981; Chavaillon \& Piperno 2004), these percussive items are abundant, and have been used as chrono-cultural markers to differentiate the Oldowan from the Developed Oldowan (e.g. Leakey 1971, 1975).

Further studies of several Olduvai assemblages have revealed an even greater frequency of percussion tools (Mora \& de la Torre 2005; de la Torre \& Mora 2005). This reanalysis highlights the great amount and variety of stone tools linked to percussive activities. The morphology of pieces indicates that percussion materials were not always related to knapping, but to other working processes. Before verifying through systematic use-wear and experimental analyses, it is risky to speculate what type of functional activities these stone tools were involved with. Nonetheless, we consider that, on the basis of a technological approach, it is possible to evaluate the prevalence of the battered items, and to assess whether they can be included in the chaînes opératoires of débitage, or are a result of other stone tool use operations.

Under these premises, and assuming the distinction between active percussion elements (hard pieces that transmit a force intended to modify another item - fig. 1a-) and passive percussion elements (hard pieces that receive the force transmitted by another item, either to modify the trans- mitter object - fig. 1b - or another intermediate piece between the transmitter and the receptor -fig. 1c-), in the following sections different types of percussive tools from Olduvai Bed I and II assemblages are discussed.

\section{Active percussion elements}

\section{Active hammerstones used for knapping activities}

The most common active hammers in any palaeolithic archaeological site are hammerstones used to hit another lithic item. Although characteristics of these hammerstones
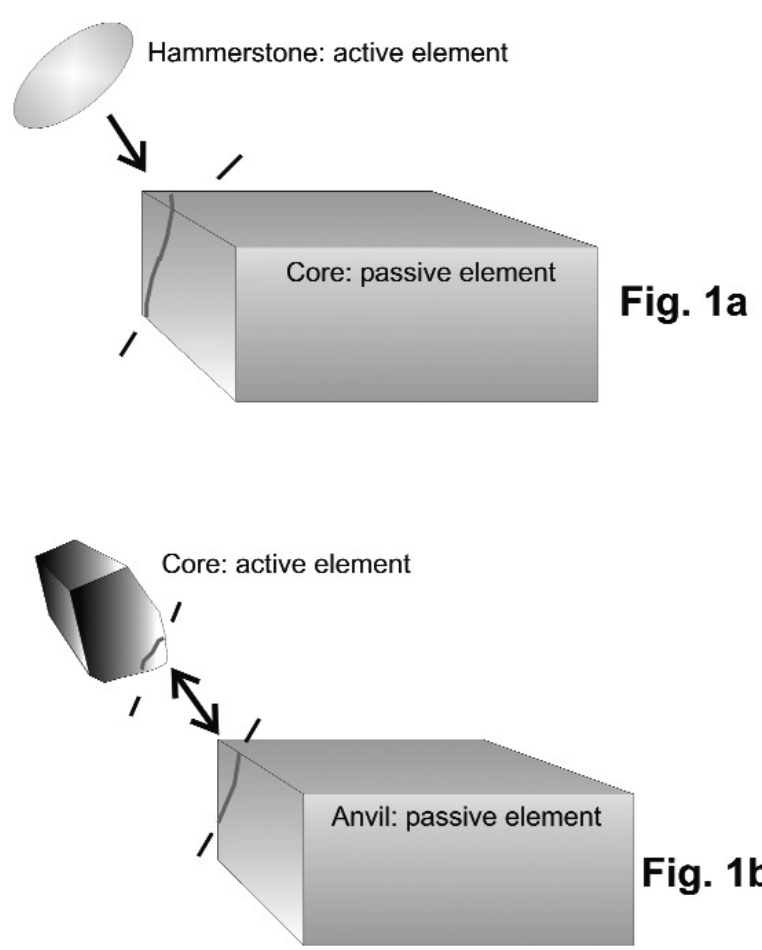

Fig. 1b



Fig. 1c

Figure 1 - Diagram of the different modalities of interaction between active and passive percussion elements.

Figure 1 - Schémas des différentes modalités d'interaction entre éléments de percussion actifs et passifs. 




Figure 2 - Examples of classic knapping hammerstones from DK.

Figure 2 - Exemples de percuteurs liés à la taille classique du site DK.

are well known, it might be useful to review their main features here, because in the Olduvai sequence they are not the only type of active hammerstones. Typical hammerstones are naturally rounded forms, usually from fluvial contexts, devoid of intentionally made modifications and with a weight and morphology suitable to be hand held. Even in some of the earliest Oldowan assemblages (Delagnes \& Roche 2005), the main feature identifying items as hammerstones is the presence of areas with concentrated pitting, which depending on the intensity of use may provoke shattered surfaces.

The main requisite of hammerstones used for stone knapping is that the area of the piece that came into contact with the core maintains a compact and homogeneous structure. In order to produce a conchoidal fracture on the core, the force must be transmitted from the hammerstone uniformly; even distribution of force does not occur when hammerstones are fractured, so when this happens, the area used for knapping is rotated or the piece is discarded.

Although percentages vary throughout the Olduvai sequence, classic hammerstones are identified in all the assemblages. Fluvial cobbles are often the blanks used as hammerstones, thus showing rounded surfaces with ergonomic shapes suitable to be hand-held (fig. 2). Predominant raw materials are lavas (mainly basalts, trachytes and phonolytes), which appear in greater percentages than quartz (fig. 3). There is an increase of quartz hammerstones in the more recent sites such as FC West

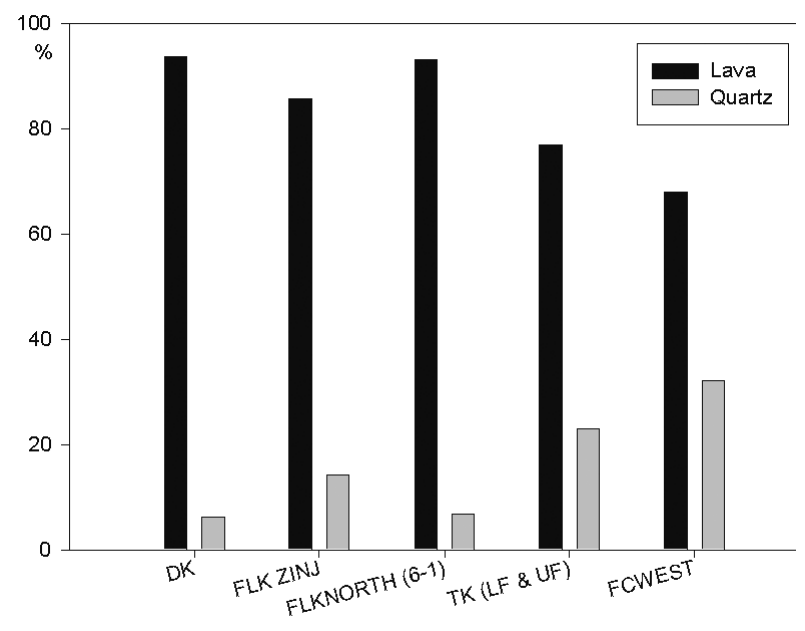

Figure 3 - Distribution by raw materials of the knapping hammerstones in some sites of the Olduvai sequence.

Figure 3 - Distribution par matières premières des percuteurs de quelques sites de la séquence d'Olduvai. 




Figure 4 - Size (length and width) of the classic hammerstones in several of the analysed sites.

Figure 4 - Dimensions (longueur et largeur) des percuteurs classiques dans plusieurs des sites analysés.

and TK. This tendency has been associated by some authors (i.e. Schick \& Toth 1994; Jones 1994) with the discovery of the advantages of quartz, which is thought to be a better raw material for hammerstones, given its greater plasticity to absorb impacts. However, that trend is not so obvious in Olduvai, where even when quartz was used as the predominant raw material, hammerstones were usually made of lava. Thus, there is an intentional selection of specific lavas when choosing hammerstones. This selection is probably related to the greater proximity of streams transporting lava cobbles, and to the natural shape of the blanks, since most of the lavas show rounded fluvial forms that facilitate their use as knapping hammerstones. In contrast, quartz usually presents a tabular and angular shape that is not suitable for this task.

Selection of lava cobbles as hammerstones is not the only pattern noticeable throughout the Olduvai sequence. For example, there are many cores that were previously used as hammerstones, showing a pitting on the cortical area at the opposite side to the knapping surface. The multi-functionality of cores-hammerstones is particularly frequent in Bed I sites such as FLK Zinj and FLK North (where over $23 \%$ of the cores show battering marks), albeit they are also present in later assemblages such as FC West and both levels of TK. This shows the multiple meanings of categories created by archaeologists and, at the same time, informs on the technological flexibility of the chaînes opératoires we are analysing.

Another noticeable trend is the metrical homogeneity of classic hammerstones throughout the Olduvai sequence. There is a maximum size ranging between $70-80 \mathrm{~mm}$ (fig. 4) and all items are very similar in their mass, ranging between 350-380 grs in FLK Zinj, FC West and FLK North, and 410$450 \mathrm{grs}$ in TK and DK. It is difficult to assess whether this is due to the availability of cobbles of a determined size in the nearby streams, or whether it is an intentional selection of optimal blanks to be used as hammerstones.

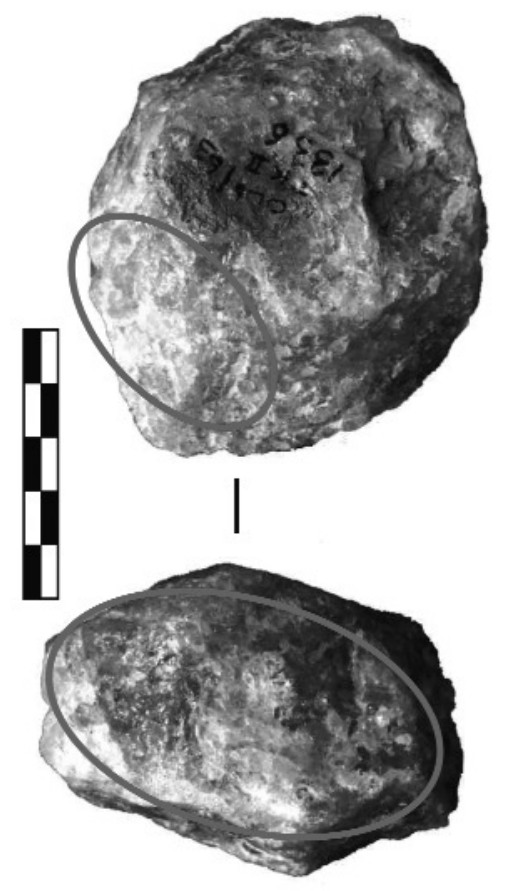

Figure 5 - Example of a typical hammerstone with fracture angles from TK Upper Floor. Circles indicate battering areas.

Figure 5 - Exemple d'un percuteur avec angles de fractures typique du site TK Upper Floor. Les cercles indiquent des zones percutées. 


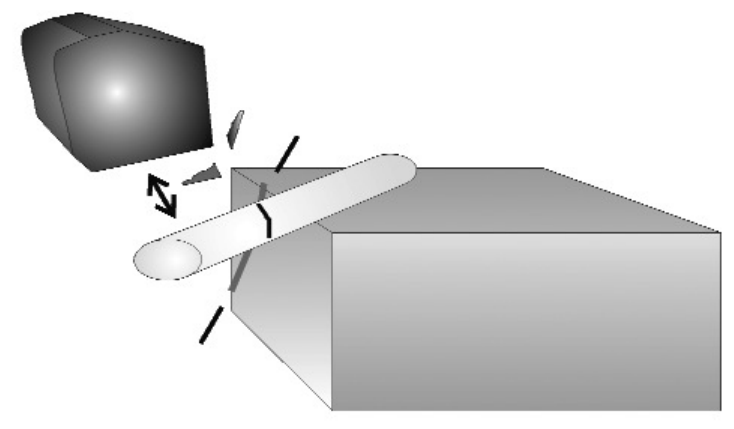

Figure 6 - Diagram of the process entailing the fracturing of the hammerstone that leads to the detachment of fragments from both sides of the ridge.

Figure 6 - Schéma du processus impliquant la fracturation du percuteur qui conduit au détachement de fragments des deux côtés du bord.
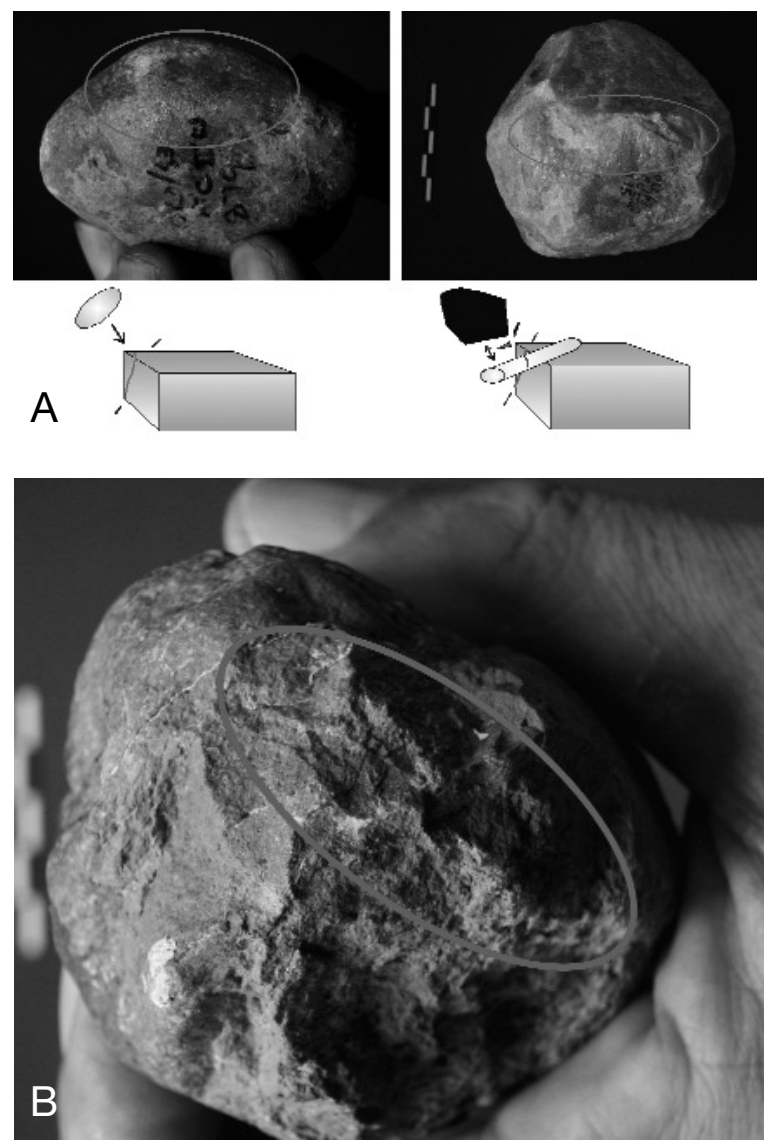

Active hammerstones with fracture angles

Leakey (1971) included in the category of classic hammerstones all pieces she considered active hammers that did not show intentional shaping. However, we have identified a large number of items that -although they present the battering typical of active percussion activities- actually are not the classic hammerstones used in knapping processes. These items have been grouped under the term "active hammerstones with fracture angles".

If classic hammerstones are characterised by being rounded cobbles with pitting on cortical and/or even surfaces, hammerstones with fracture angles show battering traces along orthogonal planes. Such fractures are generated by percussive processes; when hitting an item with the hammerstone, the active element is fractured, producing orthogonal planes and irregular ridges. Instead of replacing the hammerstone or using an undamaged area from the same piece -as occurs with classic hammerstones- in this case the damaged angles are used to continue banging the passive item, so that the surface used for striking becomes heavily fractured (see fig. 5).

During this process, fractured planes are abraded by the battering, presenting sinuous edges along the ridge's silhouette. Fractures are caused by "simultaneous scars" on both sides of ridges: when hitting the edges generated by previous battering, the impact force provokes new fractures and by-products are detached from both sides of the ridge, often simultaneously (fig. 6).

Sometimes it is difficult to distinguish negatives generated involuntarily by percussion activities from those made by knapping. This is probably why in the original classification (Leakey 1971) some items were described as choppers and polyhedrons when they actually did not experience any knapping, but had instead been fractured by percussion processes. Many of the hammerstones with fracture angles have similar edges and scars to those shown by core types such as choppers. However, the similarity is only morphological, for hammerstones with fracture angles show features that are not related to the principles of conchoidal fracture: there are no impact points on the negatives, nor do such impact points stem from the edge of the piece but from the central part of the negative. Scars have irregular shapes without a set directionality, whilst the edges of ridges present rims unlikely to have been generated by conventional knapping methods. Moreover, step and plunging scars cover most of the surface, forming blunted areas with angles unsuitable for obtaining flakes. These features, altogether with the battering of ridges and the convex angles on the detachments, suggest that these stone tools were made by activities other than knapping.

Figure 7 - A) Comparison between a classic hammerstone (left), which shows a homogeneous pitted surface, and a hammerstone with fracture angles (right), showing a battered dihedral ridge. Both samples from FC West Occupation Floor. B) Detail of the battering on the ridge of a hammerstone with fracture angles from FLK North (Level 5).

Figure 7 - A) Comparaison entre un percuteur classique (à gauche), présentant une surface piquetée homogène, et un percuteur avec angles de fracture (à droite), présentant une arête dièdre percutée.

B) Détail de la surface de percussion sur l'arête d'un percuteur avec angles de fracture de FLK North (Niveau 5). 
Consequently, we can speculate about the functionality of this type of hammerstone. Hammerstones with angle fracture usually present an unmodified holding surface, whilst the opposite area is covered by battered ridges broken during the percussion process. Angles and irregularities on the percussion surface suggest that these items could not have been used as lithic knapping hammerstones: there are no even areas on their surfaces which, upon coming into contact with the hammered item, could transmit the force uniformly in order to generate a conchoidal fracture (fig. 7a). Quite often classic hammerstones end up breaking during their use, and this could lead the hypothesis that hammerstones with fracture angles are simply broken knapping hammerstones. However, in hammerstones with fracture angles the battering affects previously broken edges; this suggests that the ridges generated by fractures were used repeatedly to bang after they were no longer effective for percussion activities related to lithic knapping (in which even surfaces are required). Thus, the fact that battering marks appear on the ridges (fig. $7 \mathrm{~b}$ ) seems to indicate that it was precisely these natural angles created by percussion which were used to perform the task. Although use-wear analyses are not available as yet, it can be tentatively suggested that these objects might have been used for the chopping of wood, bone or other organic elements, as well as any other heavy duty processes related to crushing.

There are two patterns within the group of hammerstones with fracture angles. First, in some of the items the battered section is located along a large surface altered by orthogonally fractured ridges (fig. 5). Alongside this type of hammers with battering distributed along several fracture planes, there are others in which percussion seems to have focused on one ridge, attaining a dihedral angle (fig. 6). This technical gesture requires the combination of two factors: a force applied severely, and an obtuse dihedral angle that could resist the impacts against the material being processed.

The identification of hammerstones with battered dihedral angles leads to discuss about the meaning and validity of the term chopper, as defined by Mary Leakey. This author considered choppers as genuine tools and not mere cores because of their characteristic shape; intentional shaping would create a unifacial (chopper) or a bifacial (chopping tool) edge with simple angles, opposed to a cortical and /or rounded "ergonomic" end, therefore making these items supposedly ideal for chopping activities similar to those described above. However, after the formal definition of choppers (e.g. Leakey 1971), over the last decades it has been questioned that choppers are standardised artefacts, being proposed that these items were just cores used to detach flakes (Isaac 1986; Toth 1985, etc).

Regardless of the typological and even technological aspects involved in the manufacturing of choppers, the point is that, when these objects are used for heavy duty activities such as chopping wood or breaking bones, traces generated on the ridges are always visible and even conspicuous to the naked eye, as demonstrated by experiments (e.g. Ashton et al. 1992). Due to diagenesis or fluvial processes affecting preservation of stone tools, it is difficult to notice these traces at some early archaeological sites. However, this is far from a problem in Olduvai, where preservation is generally excellent. Thus, if the unifacial or bifacial objects with partial edges and simple angles from Olduvai had been used for chopping activities, the damage on their ridges (pitting, abrasion, step fractures, etc) would be perfectly visible.

This is not the case in any of the analysed assemblages at Olduvai, in which the chopper-type cores usually show undamaged knapping edges (fig. 8). As stated before, the lack
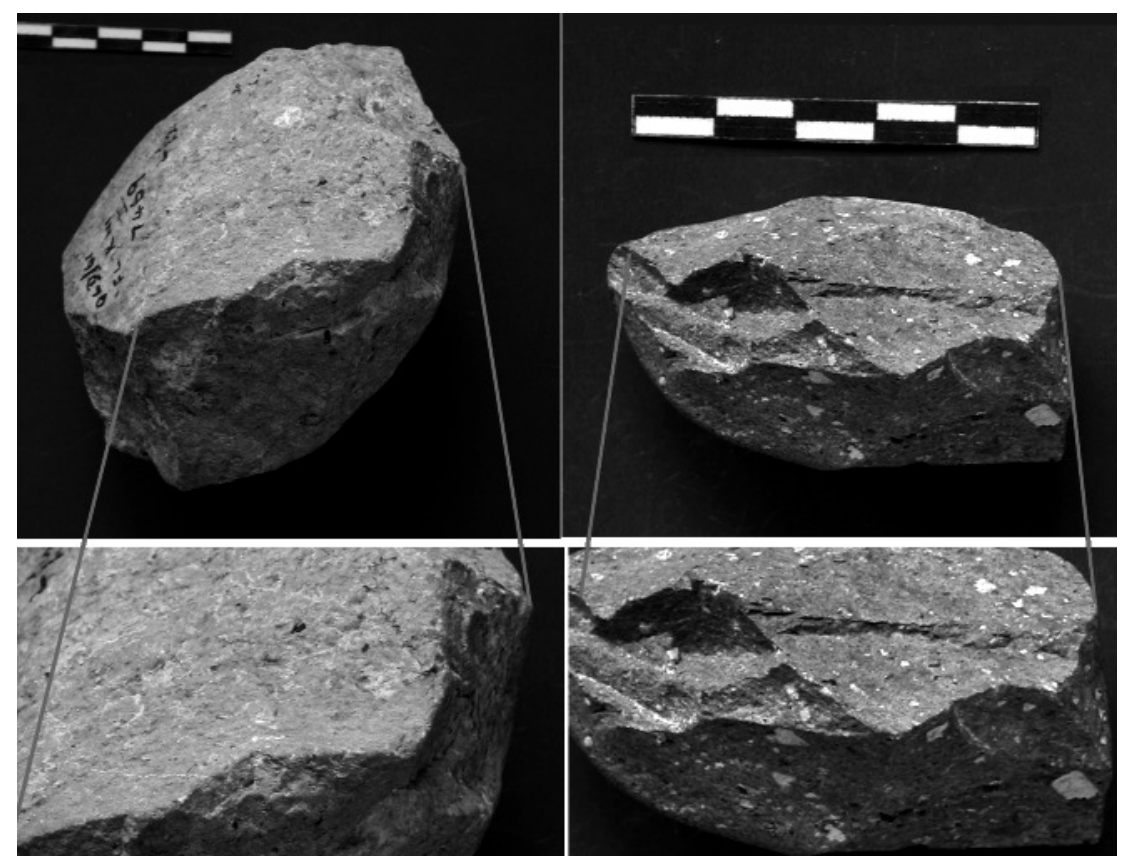

Figure 8 - Detail of the intact ridges of choppers from FLK North. Note lack of battering on the edge of the pieces.

Figure 8 - Détail d'arêtes intactes de choppers de FLK North. Noter l'absence de traces d'impact sur le bord des pièces. 

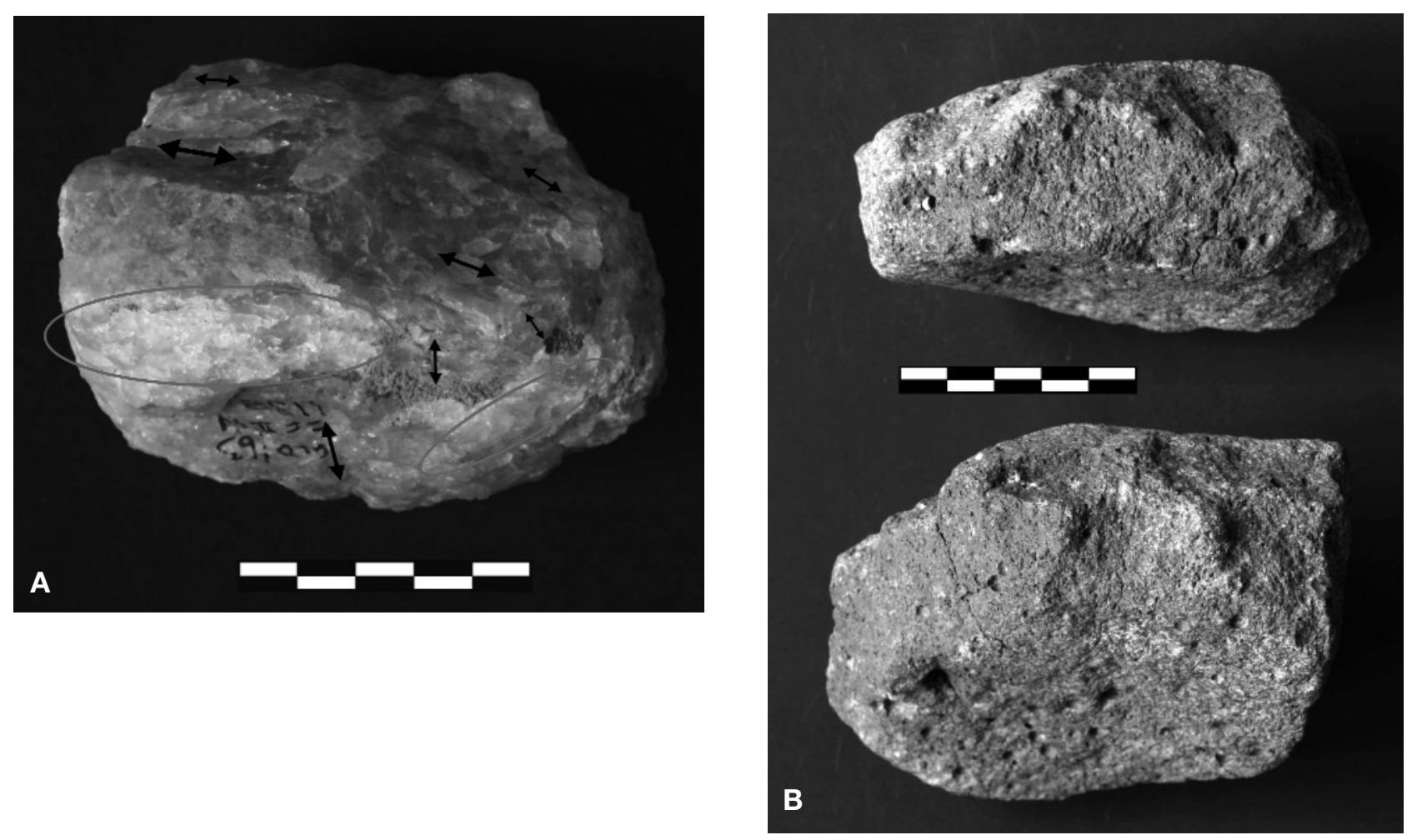

Figure 9 - A) Example of a hammerstone with fracture angles from FC West Main Floor, classified originally by Leakey (1971) as a chopper. B) Example of chunk devoid of traces of human modification from DK, classified originally as a chopper.

Figure 9 - A) Exemple de percuteur à angles de fracture de FC West Main Floor, classifié à l'origine comme chopper par Leakey (1971). B) Exemple de bloc dépourvu de traces de modification anthropique de DK, classifié à l'origine comme chopper.

of traces denoting use on the ridges of choppers cannot be put down to preservation factors. In fact, many of the cortical areas opposite the knapping surface show visible battering that is indicative of their multi-faceted use as hammerstones. If the ridges had also been used for the chopping activities the typological definition proposes, battering marks also should appear on the edges. Thus, as far as Olduvai is concerned, it does not seem appropriate to grant choppers a functional meaning, since these tools -even in their name itself-suggest a purpose that has not been proved.

As stated above, it is likely that many hammerstones with fracture angles were used precisely for chopping activities. Sometimes, as in the case of the active elements in which the battering is focalised on a ridge, morphological similarity between such hammers and chopper-type cores is remarkable. The essential difference is that core edges from choppers are created by intentional knapping processes aimed to obtain flakes, and do not present traces of battering or use. Conversely, ridges from hammerstones with fracture angles are caused by percussion activities, with irregular, battered and stepped scars. This would explain some of the mismatches with Leakey's (1971) classification, who included in the category of flaked objects items that we believe do not correspond to débitage or façonnage processes, but instead to percussion activities (fig. 9a) or even to natural processes (fig. 9b) .

\section{Subspheroids, spheroids and stone balls}

Worked stones with spheroid shapes have been widely discussed in the Early Stone Age literature. The pioneering work of Clark (1955) defines stone balls and similar items as pieces flaked until obtaining a spherical shape, which show intentional battering in order to blunt the ridges. According to Clark (1955), spheroid pieces would be processed on an anvil, detaching small fragments until achieving a rounded shape. Clark also explored the functional meaning of spheroid items, proposing their use as missiles, without ruling out that they also could be hammerstones used for knapping or crushing nuts.

Later, Kleindienst (1962) established three categories, missiles (natural pieces with no human modification), polyhedrons (objects with several facets and negatives) and bolas (quasi-spherical pieces with a smooth surface obtained by battering processes). Successive typological proposals (e.g. Leakey 1971; Clark \& Kleindienst 1974) kept classifying spheroids and subspheroids as tools with intentional and standardised shapes. Leakey (1979) also suggested these spherical pieces were used as missiles, a popular idea followed by several authors (B. Isaac 1987; Bingham 2000; Calvin 2002, etc). In recent decades, discussions over the analysis and interpretation of spherical forms in the Early Stone Age continued, considering both the analysis of 
archaeological assemblages (e.g. Willoughby 1987; Sahnouni 1991, 1998; Jones 1994), and experimenta replications (Schick \& Toth 1994; Sahnouni et al. 1997; Texier \& Roche 1995).

Willoughby (1987), as did Leakey (1971), argued that spheroids and similar forms are diagnostic markers between different cultural facies at Olduvai, pointing out their high frequency during the Developed Oldowan B (sensu Leakey 1971). According to Willoughby (1987), spheroids could be the end result of a continuous reduction process that would commence with choppers and continue through polyhedrons and subspheroids. Willoughby (1987) also suggests that spheroid forms could have been hammers associated to anvils, since according to her there is a correlation between the frequencies of both types of tools in the Olduvai sequence. She believes that spheroids were linked to pounding activities, and that instead of being an intentional end product, it is more likely that tools acquired a spherical form through their use as hammers (Willoughby 1987).

According to Schick and Toth (1994), the systematic use of exhausted quartz cores as hammers would have led to heavily battered rounded items. Those we now classify as spheroids would not be predetermined forms but instead objects unintentionally rounded during their use as hammerstones. Sahnouni et al (1997) test this hypothesis, and point out that a moderate reduction of cores tends to produce unifacial or bifacial choppers, whilst more intense reduction leads to polyhedrons and some subspheroids and, eventually, faceted spheroids. They conclude spheroids are not predetermined pieces, but exhausted cores that later on were used as battering objects (Sahnouni et al. 1997).

Texier and Roche (1995) present a different view, in which spherical objects are the result of a well-reasoned organisation of shaping. Thus, polyhedrons, spheroids and subspheroids would be different stages of the same chaine opératoire, in which these pieces are not by-products of débitage and battering processes, but the consequence of an intentional façonnage (Texier \& Roche 1995-p. 35). According to these authors, polyhedrons, subspheroids and spheroids proceed from the same concept, the controlled reduction of a blank to obtain a regular volume distributed on the basis of a virtual point that has a centre of symmetry, in other words a sphere. Considering Willoughby's proposal (1987) on the positive correlation in the representation of spheroids and anvils in the Olduvai sequence, Texier and Roche (1995) make an observation that echoes Clark's (1955) conclusions; to control the effectiveness of percussion when shaping spheroids, the best option is to work the polyhedron on a hard surface: thus, percussion becomes bipolar due to the effect of the active hammerstone and the anvil. This creates numerous battered areas that give the piece a regular, spherical shape.

Despite the opposing viewpoints between those considering polyhedrons, spheroids, etc as mere hammerstones (Schick and Toth 1994; Willoughby 1987; Sahnouni et al.
1997), and those who believe they are the end product of an orderly and preconceived façonnage (Wynn 1989; Texier and Roche 1995), all authors concur that polyhedrons, subspheroids, spheroids and bolas are different stages of the same process. This pattern has been suggested in the practical examples of Ain Hanech (Sahnouni 1998; Sahnouni et al. 1997) and Isenya (Texier \& Roche 1995; Roche \& Texier 1996).

However, such a continuum cannot be supported for the case of Olduvai. Jones (1994) highlighted that most of polyhedrons in both Beds I and II were manufactured from lavas, whilst spheroids and subspheroids were almost invariably made of quartz. Therefore, Olduvai polyhedrons and subspheroids/ spheroids could not be consecutive stages of the same chaîne opératoire, since raw materials used in the production of each artefact type are different. This problem does not only arise in Olduvai; in Ubeidiya, for example, polyhedrons are primarily made in chert, and spheroids in limestone (Willoughby 1987; Bar-Yosef \& Goren-Inbar 1993), and even in Isenya polyhedrons and spheroids are fundamentally made in phonolite whilst bolas are made of quartz (Roche \& Texier 1996).

Going back to Olduvai, Jones (1994-p. 276-277) also provides convincing morphometric arguments, as he demonstrates that it is unlikely for subspheroids to come from polyhedrons; upon analysing the size of both samples, subspheroids are generally larger than polyhedrons, hence subspheroids could not have been produced during a later reduction sequence. Consequently, Jones (1994) concluded that the processes that generated spheroids and subspheroids, linked to intense percussion activities, were unrelated to the knapping processes envisaged in the production of Olduvai polyhedrons.

Our review of Olduvai assemblages suggests that some of the items Leakey (1971) classified as polyhedrons are unmodified natural pieces, whose multiple angles and ridges were caused by casual fractures, not by knapping or pounding processes. In many of the so-called polyhedrons, the supposed flake extractions do not show negative bulbs, or such concavities are located on the central part of the scar, negatives present impossible angles, natural ridges, etc (fig. 10).

Only a few cores have been assigned to the polyhedral system that, according to the original definition (Leakey 1971-p. 5), requires at least three or more working edges, and there are even less that could be included in polyhedral strategies as understood by specific technological definitions (Inizan et al. 1995; Texier \& Roche 1995). Most of the polyhedrons we have identified are quite small, made of lava and do not show traces of battering, i.e. they do not seem to be related to percussion but with knapping processes. Thus, our conclusions based on a review of technological categories comes to support Jones (1994)'s statistically- based proposal about the mismatch between polyhedrons and subspheroids/ spheroids at Olduvai; quartz subspheroids and spheroids belong to a sequence different from that of the polyhedrons. 


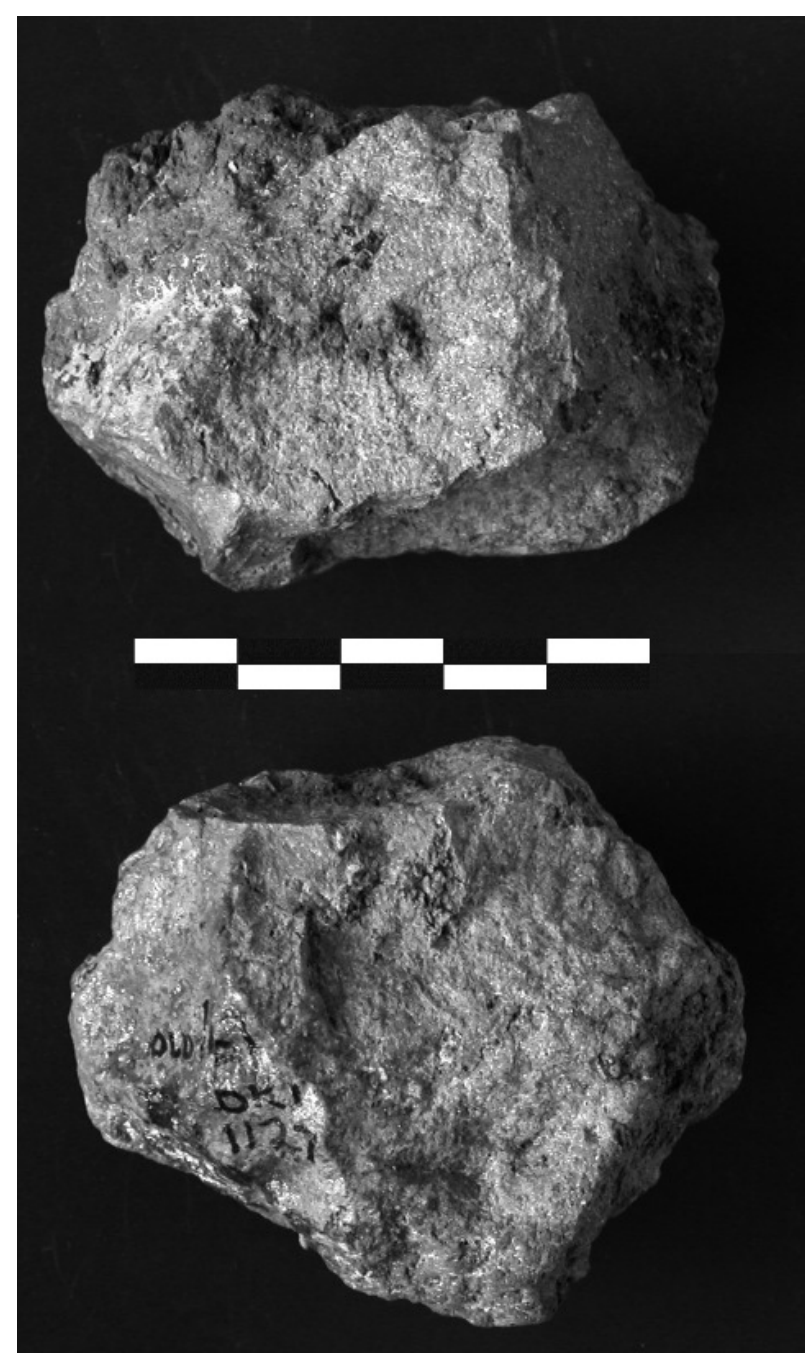

Figure 10 - Examples of natural chunks without human modification from DK, classified originally as polyhedrons.

Figure 10 - Exemples de blocs dépourvus de traces de modification anthropique de $D K$, classifiés à l'origine comme polyèdres.
Concerning the study of Olduvai spheroids, the first problem concerns the differentiation between humanmade artefacts and pieces with naturally rounded forms. As pointed out by Willoughby (1987), natural spheroids are not rare, being caused by different processes such as fluvial abrasion, volcanic lapilli and even spheroid weathering, in which rocks exfoliate due to chemical alterations. Therefore, some of the objects classified originally as spheroid artefacts are, in fact, naturally rounded pieces.

Conversely, some of the items considered as subspheroids or spheroids are, according to our study, detached chunks showing battering marks, and not pieces that have been used directly for percussion activities. Such items are just fragments that have come detached by the battering (hence the damage traces on their dorsal faces). Thus, the fact that a number of small fragments detached from genuine percussive tools were originally classified as spheroids or subspheroids, suggests that percentages of these tool types are lower than originally proposed by Leakey (1971). This mismatch is not exclusive from Beds I \& II, since Jones (1994) points out that many of the so-called subspheroids in Bed III, Bed IV and the Masek Beds were merely chunks or broken artefacts.

Focusing on sites such as FC West and TK (Lower and Upper Floor) in Bed II, there are two patterns within the quartz battered items that were originally classified as polyhedrons, subspheroids and spheroids. This dichotomy can be established on the basis of the sedimentary origin of quartz blanks. Although the quartz used in the Olduvai sites is normally tabular, there are also (especially in Bed II) quartz cobbles from streams. This distinction was not considered in the original classification by Leakey (1971), and as a consequence the same category of spheroids included items with disparate sedimentary origins. The fact is that many of the so-called spheroids are quartz cobbles with natural rounded shapes. These pieces show traces of battering that indicate their use as hammerstones, and probably it is the



Figure 11 - Example of a quartz cobble with a cortical surface modified by battering from FC West.

Figure 11 - Exemple de galet de quartz de FC West présentant une surface corticale modifiée par percussion. 
intensity of pitting which led to their classification as spheroids. Even though they could ultimately be used for the same tasks as other spheroids, the morphological genesis process is different to that of tabular blanks, since quartz cobbles have a naturally rounded shape (fig. 11). Therefore, the chaine opératoire of many of the Olduvai spheroids is different from that designed by Texier and Roche (1995), who proposed a knapping process devoted to the shaping of spherical items; as regards quartz "spheroids" from cobble blanks, the original piece is already rounded and show cortical surfaces used for percussive activities. Eventually, irregular edges are caused by pounding, and ridges finally become rounded again given the intensity of battering.

The process involved in the production of spheroid shapes from tabular quartz blanks is different. Some of the so-called polyhedrons have no intentional scars created during knapping, but orthogonal planes and intense battering on the ridges produced by their use as active pounding elements. They represent what we call the first step (stage 1) of use of the quartz blocks, and include the various types of hammerstones with fracture angles described above. When pounding items continue being used, battering spread all over the piece and ridges collapse, blunting the original facetted shape of quartz blocks. In order to integrate items in classifiable categories, we have included these pieces in a stage 2 of modification, although it is the same process as that of the previous stage, but entailing a greater level of percussion intensity and/or a longer use (see fig. 12). Finally, in Olduvai Bed II there are quartz tools totally rounded by battering; these items can be considered as shaped or "genuine" spheroids, and compose stage 3 or the final phase of modification, once they have lost completely their original tabular shape.

The distinction between subspheroids and spheroids in tabular blocks and quartz cobbles is relevant, since these items are being included in categories that are morphologically similar but which, nonetheless, have different sedimentary and technological backgrounds: so-called spheroids on cobble blanks can be distinguished from the spheroids made by the battering of natural ridges on tabular flocks, since the former, although their whole surface may present battering, still preserve fluvial cortex and a naturally rounded shape.

Regarding those items that really experience shape modification (i.e. quartz tabular blocks), the process observed in Olduvai Bed II is the same as the one proposed by Schick and Toth (1994) and Jones (1994); quartz blocks, after being used as hammerstones, end up taking on a rounded, spherical shape. At Olduvai, there are tools in different stages of use that allow reconstructing technical gestures embodied in the shaping of spheroid morphologies.
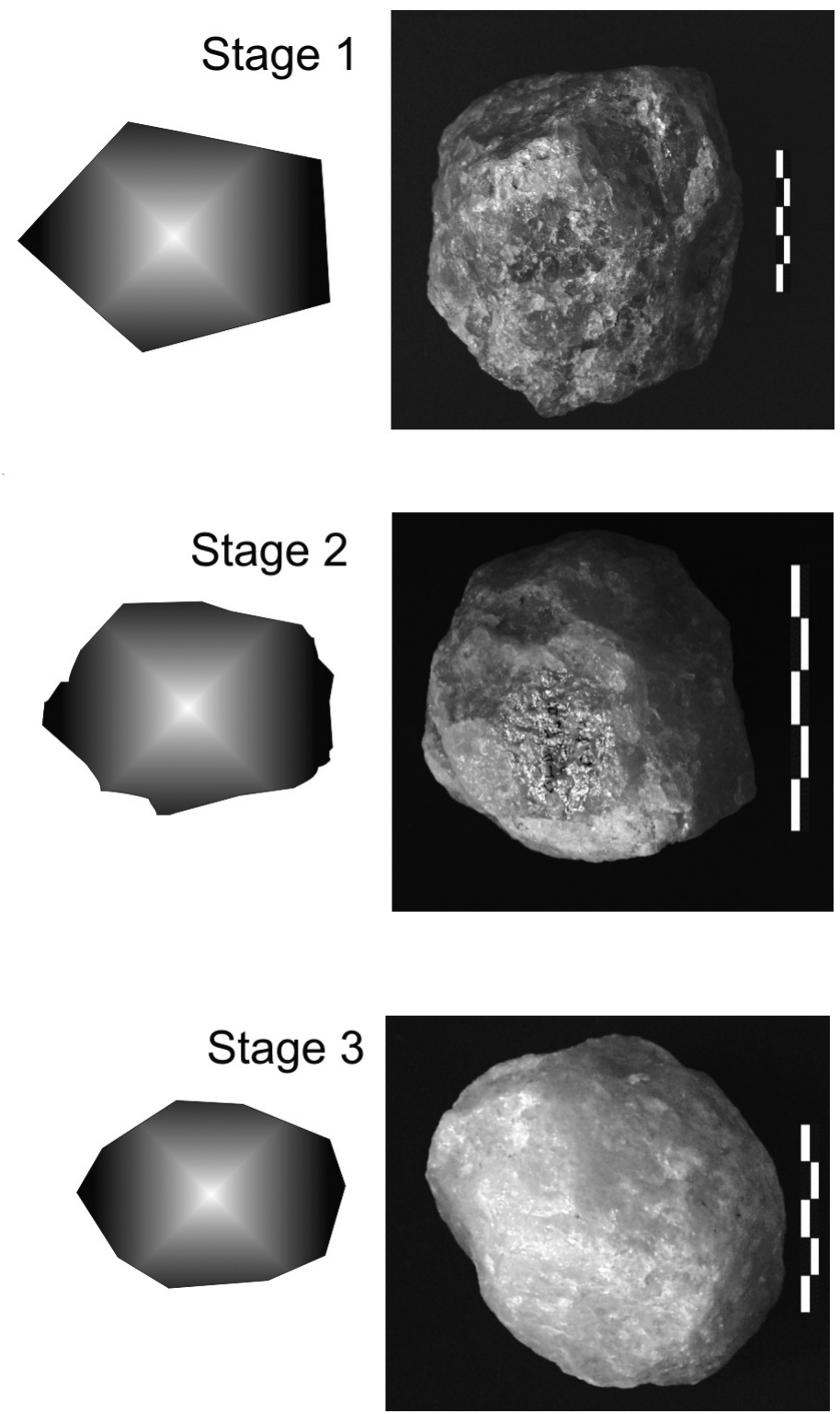

Figure 12 - Examples of so-called subspheroids and spheroids from FLK North (Sandy Conglomerate Level) and diagrams representing the ideal stages of the reduction of the quartz blocks, from an initial battering stage on the ridges with angular fragments, to the final stage envisaging the rounding of the spheroids (from Mora \& de la Torre 2005).

Figure 12 - Exemples de dits sub-sphéroïdes et sphéroïdes de FLK North (Sandy Conglomerate Level) et schémas montrant les phases théoriques de réduction des blocs de quartz, depuis un stade initial de percussion des arêtes de fragments anguleux, jusqu'à un stade final aboutissant à des sphéroïdes (d'après Mora et de la Torre 2005). 
As stated above, genuine lava polyhedrons are linked to stone tool knapping and generally have no battering traces. However, many of the so-called quartz polyhedrons are actually hammerstones with natural fracture angles and do not present scars that could link them to débitage or façonnage activities. Not even the objects most affected by battering do show traces of intentional knapping, their shape modifications being caused by pounding processes.

We consider that, at least as far as the Olduvai Beds I and II are concerned, there is no façonnage of polyhedrons and spheroids, and rounding of quartz blocks is caused by intense battering of artefacts. A different question is whether the rounding of these tools is intentional or random. As mentioned before, Schick and Toth (1994) considered that they are casual shapes derived from their use as hammerstones. On the opposite side, it has been proposed that the spheroids are preconceived morphotypes obtained from façonnage (Texier \& Roche 1995). According to these authors, spheroids cannot be merely hammerstones since the latter generally have one or two battered ends, whilst the whole of the spheroid surfaces are completely battered (Roche \& Texier 1996; Willoughby 1987). Jones (1994) offers an intermediate position; in spite of considering that the swiftest manner to obtain spheroid forms is by using pieces as hammerstones, he considers it must have been a deliberate option by the worker, in an attempt to produce round shapes suitable for particular purposes.

Long ago, Desmond Clark (1955) pointed out that the spheroid phenomenon is found all across Africa and ranges over an extended period of time, which starts at the Olduvai sites and continues throughout the Acheulean and the Middle Stone Age. This morphological standardisation, linked to the heavy battering visible on many spheroids, seems to be indicative of a certain interest in attaining evenly rounded shapes (see also Wynn 1989). The fact that blocks were used for percus- sion activities during a certain stage (our stage 1) in which, due to the uneven character of tabular shapes, they could not have been used as classic hammerstones, makes it hard to believe that the intense battering processes that led to the obtaining of completely spheroid shapes (stage 3) are linked to lithic knapping. Consequently, other functional alternatives for these active hammerstones should be sought, even though they still are to be verified by use-wear and systematic experimental analyses.

\section{Passive percussion elements}

Passive hammerstones or anvils, i.e. the elements that receive the force transmitted by another item, constitute another relevant tool type in the Olduvai sequence. Leakey (1971) pointed out that during the Oldowan, unmodified cuboid blocks and cobblestones were selected as anvils, whereas in the Developed Oldowan such blanks would be shaped before they were used. According to Leakey (Leakey \& Roe 1994), this type of anvils is rarely found in Beds III and IV, where pitted anvils predominate. These pitted anvils are described as boulders and cobbles with pecked depressions (isolated or in pairs) which would be associated with the bipolar flaking technique and the obtaining of outils écaillés (Leakey \& Roe 1994). In earlier sites at Olduvai, this type of pitted anvil was only identified incidentally, as in the case of the Sandy Conglomerate Level in FLK North in Lower Bed II (Leakey 1971 plate 17). However, even this case is dubious, and we believe it is difficult to support that such pits are human made instead of natural. Since our study is limited to Beds I and II, we will leave aside the issue of the pitted anvils (see Jones 1994) and focus on the category of regular anvils.

The description of Olduvai anvils Leakey made (1971-p. 7) is still useful, as she considered these pieces as "cuboid blocks or broken cobblestones with edges of approximate-

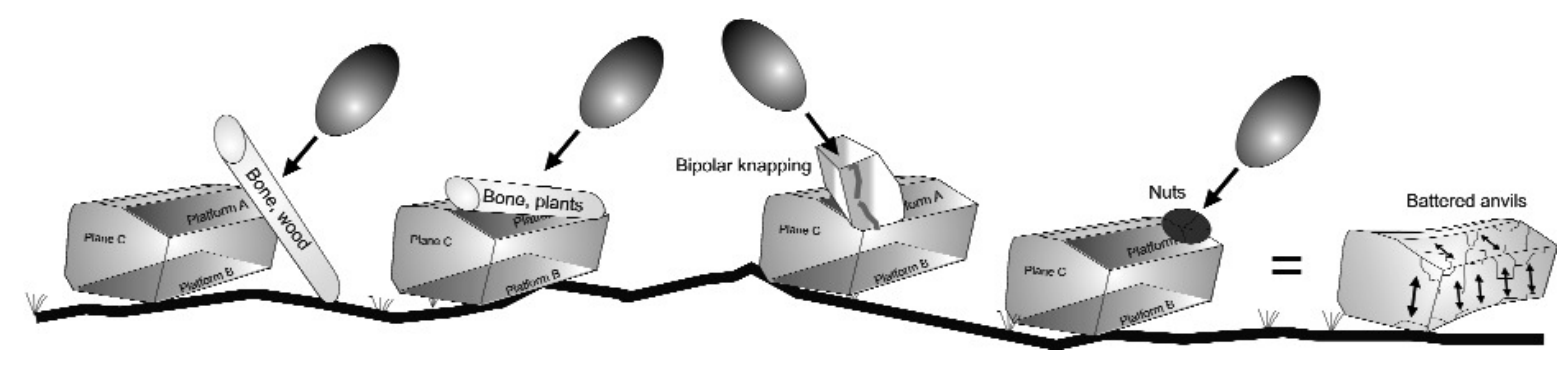

Figure 13 - Possible use of anvils.

Figure 13 - Utilisation probable des enclumes. 

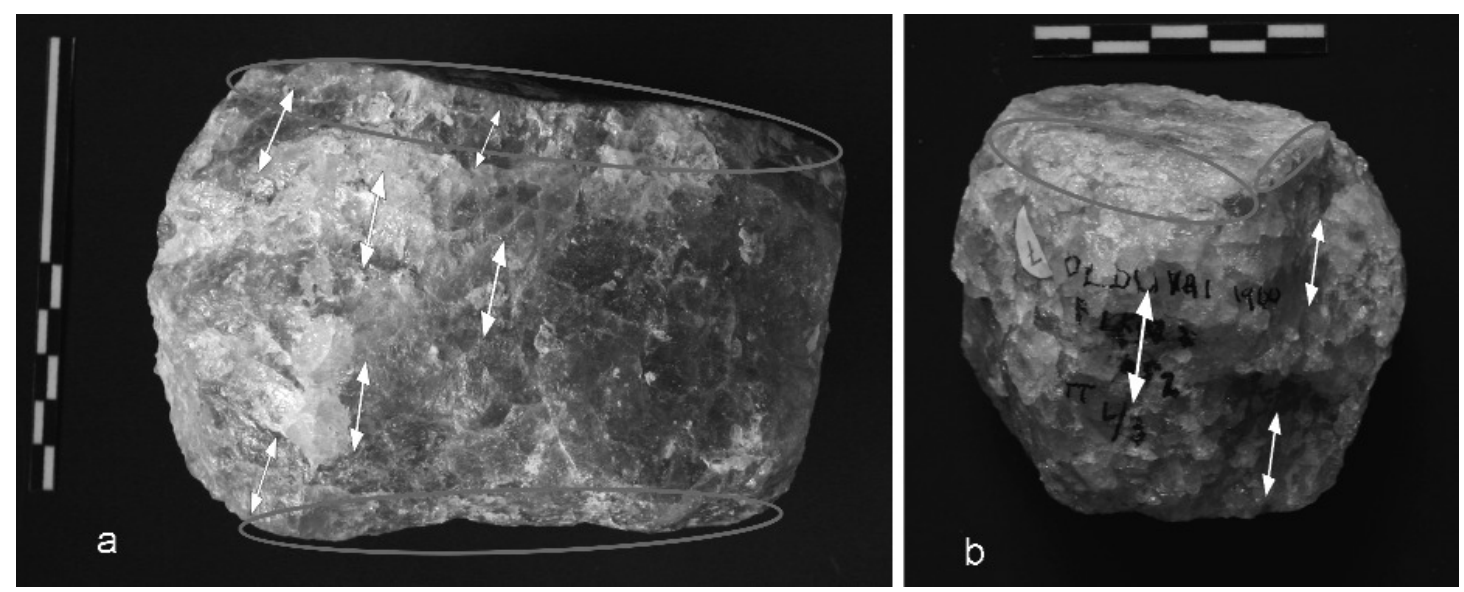

Figure 14 - Examples of quartz anvils in sites TK (a) and FLK North (b).

Figure 14 - Exemples d'enclumes de quartz des sites TK (a) et FLK North (b).

ly $90^{\circ}$ on which there is battered utilisation, usually including plunging scars". In the Olduvai anvils, natural tabular planes of quartz blocks act as platforms that receive blows from the active hammerstones. The even surfaces of these tabular blocks facilitate one of the flat sides to be used as a percussion platform $(A)$, whilst the opposite side $(B)$ is positioned on stable ground. During the percussion process (see fig. 13), abundant impact marks are inflicted in platform $A$, especially on its edges, which causes the abrading of the periphery of the anvil. Although platform $B$ does not receive direct blows, it also experiences écaillés and fractures due to the bipolar force transmitted to the block and its contact with the ground. As a result of this whole process, the surface of the block $(\mathrm{C})$ between sides $A$ and $B$ is also modified, and numerous step and plunging scars are caused all around the periphery of the block.

Dynamics involved in the using of anvils are remarkably similar throughout the whole of the Bed I and II sequence. The dominant raw material among anvils is quartz, probably due to its tabular morphology, which enhances stability of the passive element during the percussion process. Size of tabular quartz anvils (see fig. 14) is variable, ranging between 85 $\mathrm{mm}$ (e.g. FLK North Levels 6-1) and $90 \mathrm{~mm}$ (e.g. TK Lower and Upper Floors) in length and 555 gr. and 733 gr. in weight, respectively. They are not particularly large items and could be handled easily. Consequently, although there are some necessarily- static anvils such as those from MNK (samples weighing over $10 \mathrm{kgs}$ ) or SHK (with an anvil over $20 \mathrm{kgs}$.), concerning the examples from FLK North, TK or FC West, their size should not be considered as the criterion to identify these objects as anvils. Rather, the presence of opposite battered surfaces may be a more useful feature for identifying passive hammerstones.

As aforementioned, Leakey (1971) referred to shaped anvils in the Developed Oldowan, in which the flat upper and lower surfaces of blocks would be accompanied by flaking of the circumference. Despite we have document- ed some cores with battering marks on knapping platforms which indicate their previous use as anvils, this pattern entailing the reutilization of tool is not analogous to the anvil shaping process Leakey (1971) proposed. According to Alimen (1963), negatives produced during the percussion process on anvils can be differentiated from those made by flaking, and we believe it is possible to do so in the Olduvai case. Here, scars from anvils do not respond to conchoidal fracture; instead they show orthogonal morphologies and obtuse angles. Furthermore, impact points in negatives are not on the edge of one of the platforms ( $A$ or $\mathrm{B})$, but on the centre of plane $\mathrm{C}$, which is unfeasible in a knapping activity. Likewise, these scaliform scars are short, abrupt and stepped, another feature typical of percussive processes. Thus, it is more likely that in Olduvai most of anvil scars were produced by percussion processes generating involuntary modifications on the blocks, and not by intentional shaping.

Usually, negatives on plane $C$ coincide with the battering on the edges of platforms $\mathrm{A}$ and/or $\mathrm{B}$. This suggests a linking between the transmission of force in platform $A$ and the modifications on plane $A$ (battering of ridges and surface due to their contact with the element transmitting the force or an intermediate element being pounded over the anvil), on plane $\mathrm{B}$ (battering of ridges due to the tension between the force transmitted and the ground in which the anvil lies) and also plane $C$ (plunging and step scars due to the bipolar transmission of forces between platforms $A$ and $B$, and probably also due to the contact of plane $\mathrm{C}$ and the element transmitting the force or the intermediate element being pounded).

The production of involuntary scars (negatives) on block surfaces obviously implies fragments (positives) being detached from the anvils. However, most of the works attempting to offer an explanation either typological (i.e. Leakey 1971; Chavaillon 1979; Isaac et al. 1997, etc) or technological (i.e. Schick \& Toth 1994; Texier \& Roche 
1995; Sahnouni et al. 1997, etc) of percussion artefacts, have focused on the resulting tools (hammerstones, spheroids, anvils, etc), but not on the by-products generated during these activities (although see Jones 1994).

Our reanalysis has shown that at sites such as FLK North or TK, many of the pieces originally classified as flakes or flake fragments (Leakey 1971) are actually by-products detached from the anvils due to percussion activities, and not the intentional results from débitage. Those by-products share a number of features: first, they usually show battering marks on their dorsal sides. Furthermore, the majority of these positives do not have a butt, bulb, or any other attribute that could indicate the direction of the force applied to obtain the so-called flake. Likewise, their dorsal faces do not show defined ridges or scars from previous detachments.

Given their morphological patterns, several types of what we denominate "positives detached from the anvil" (see fig. 15) have been distinguished. The first group encompasses fragments that emulate edge core flakes, detaching parts of the anvil's natural percussion platform (platform A) and plane C. Some of them show triangular transversal sections and an elongated morphology (group 1.1.), whilst others are wide and short positives characterised by sagittal sections that form a simple angle, and a concave ventral side (group 1.2.).

A second type of by-products encompasses fragments detached from plane $\mathrm{C}$ of the anvil. They usually are thin fragments that present wide and short morphologies, with no butt, bulb or ridges on their dorsal face (group 2.1). These fragments produce on anvils negatives with obtuse angles and convex scars -instead of the typical concave morphology of conchoidal fracture-, and responds to superficial chipping of the blocks during the battering. Alongside those by-products, there are thick and irregular positives (group 2.2.), genuine chunks from the fracturing of the anvils. Finally, we have identified elongated fragments that can even have a butt (group 2.3.). In this case, their classification as by-products from percussion processes rather than from débitage is established given the irregularity of the dorsal face (which usually is battered but does not show scars from previous extractions), the sinuous concavity on the ventral face (rare on conchoidal fracture), and the thickness and irregularity of their edges.

This classification of positives detached by percussion is based exclusively on their morphology, since the technological process generating all these by-products is actually the same: the gradual modification of anvils' morphology due to battering during percussion activities. Nonetheless, the aim of categorizing types of percussion fragments is to underline their morphological variability and to stress the classificatory problems, which could lead to catalogue by-products generated spontaneously from the anvils as flakes and flake fragments (Leakey 1971).

Finally, we shall reflect on the functionality of anvils. In the Upper Beds, Leakey (Leakey \& Roe 1994) linked the existence of pitted anvils to bipolar knapping and the produc-
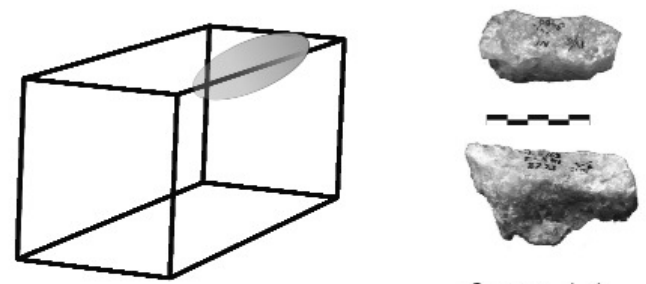

Group 1.1.
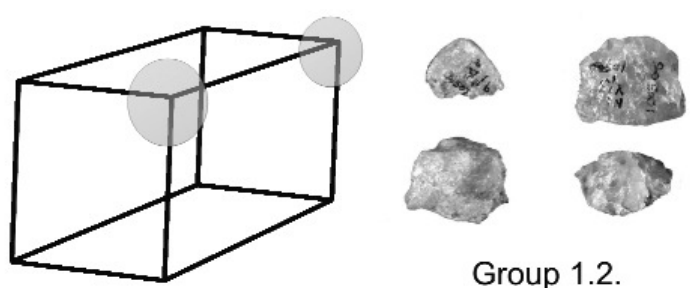

Group 1.2.


Groups 2.1. \& 2.2.
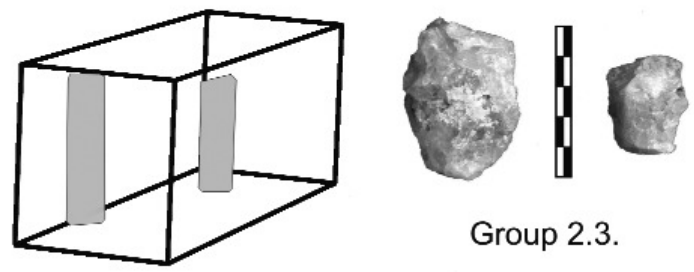

Group 2.3.

Figure 15 - Different modalities of the products generated during the activities in which anvils are used.

Figure 15 - Différentes catégories de produits générés durant les activités impliquant les enclumes.

tion of outils écaillés. Replication experiments by Jones (1994) indicate that both the outils écaillés and the punches and pitted anvils from Beds III and IV were made by the bipolar technique, i.e. detaching small quartz/quartzite flakes from a core between an anvil and a hammerstone, in a process very similar to that observed for more recent contexts (e.g. Le Brun-Ricalens 1989). However, this pattern is not found at the assemblages we have analysed at Beds I and II: therein, the so-called outils écaillés are battered fragments randomly detached from anvils, rather than flakes obtained through the bipolar technique. Furthermore, fracturing and battering all over the anvils' surfaces do not respond to the typical damage caused by the bipolar technique (i.e. the concentrated picking in some areas caused by the placement of a core on the anvil's platform), but rather suggest heavy-duty activities involving severe pounding of items. 
An alternative is that Olduvai passive hammers were part of the anvil-chipping technique, which consists on the striking of a core held in both hands against a anvil on the ground (see i.e. Shen \& Wang 2000; Kleindienst \& Keller 1976). Although we have no descriptions of the anvils resulting from anvil-chipping technique experiments, which up to now have been focused on the analysis of cores and flakes (Shen \& Wang 2000), it is unlikely that the Olduvai anvils were related to that activity; in Oldowan sites such as FLK North, flakes are always small sized, and in Acheulean assemblages such as TK, large flakes seem to have been detached by direct percussion with a hard hammerstone.

Another option could be that Olduvai anvils were used to process small nuts, as suggested in other archaeological sites (i.e. Chavaillon \& Chavaillon 1976; Goren-Inbar et al. 2002), and is widely recorded in ethological contexts (Boesch \& Boesch 1983, 1993, 2000; Mercader et al. 2002; etc). However, it is difficult to assess this hypothesis for sites such as FLK North or TK, since their anvils do not show the typical pits described at Melka Kunturé (Chavaillon \& Chavaillon 1976) or Gesher Benot Ya aqov (Goren-Inbar et al. 2002) and, even though horizontal planes (platforms A and B) present signs of battering, impacts are not concentrated on the central part but on the edges. Nevertheless, nut processing activities should not be discarded, and comparisons between anvils used by chimpanzees and those from the archaeological record are highly desirable.

As occurs in the examples described in the Sahara (Alimen 1963) and Ubeidiya (Bar-Yosef \& Goren-Inbar 1993), most of the battering on Olduvai anvils appears on the contact area between the horizontal (platforms $\mathrm{A}$ and $\mathrm{B}$ ) and transversal planes (plane C). Hence, following Bar-Yosef and Goren-Inbar (1993 p. 110) hypothesis for the examples in Ubeidiya, Olduvai anvils also could have been used for interposing elements such as bone diaphyses between the edge of the anvil and the ground. In doing so, the battering would primarily affect the ridge of the anvil, generating a large number of by-products from the damage caused to the passive hammerstone.

\section{The relevance of percussion processes in Olduvai}

After describing above the technological and morphological features of percussive tools, in this section a quantitative assessment of percussion items will be presented, with a view to evaluating the relevance of percussion processes on each assemblage. As shown in Figure 16, the volume of raw material linked to percussion processes in some sites like TK, FC West or FLK North (all levels) exceeds knapping activities. Consequently, it can be proposed that the production of tools (i.e. from knapping processes) actually had secondary importance in some Olduvai assemblages, in which there was a major focus on the intensive use of artefacts linked to percussion, perhaps bone marrow processing activities such as those proposed by Binford (1984) and Blumenschine $(1986,1995)$.

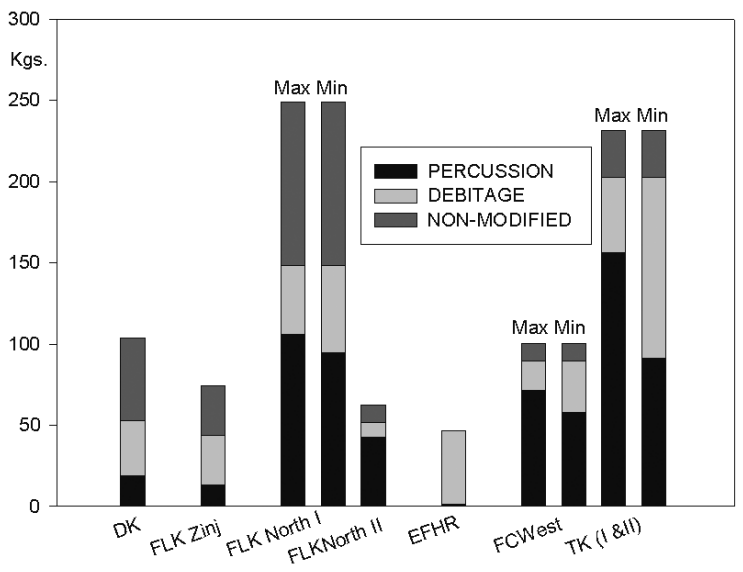

Figure 16 - Weight in kilograms of the general categories represented at each of the analysed sites. The complexity of assigning part of the products to knapping activities or to percussion activities has led to present maximum and minimum estimates for objects linked to percussion for several sites (FLK North I, FC West and TK).

Figure 16 - Masse en kilogrammes des catégories générales représentées dans chacun des sites analysés. Les difficultés rencontrées pour rattacher certains produits aux activités de taille ou de percussion nous ont conduits à présenter des estimations minimales et maximales pour les objets liés à la percussion pour différents sites (FLK North I, FC West et TK).

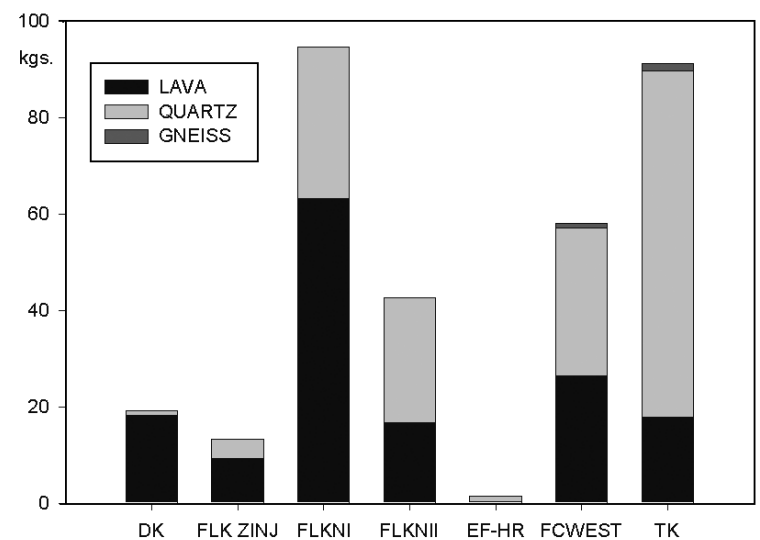

Figure 17 - Weight in kilograms of the raw materials represented for the percussion items (including active and passive objects as well as generated products) from each of the analysed sites.

Figure 17 - Masse en kilogrammes des matières premières représentées pour les éléments liés à la percussion (à savoir les objets actifs et passifs ainsi que les produits générés) pour chaque site analysé. 



Figure 18 - A) Total number and raw materials of active and passive percussion items in the analysed Olduvai sequence (DK, FLK Zinj, FLK North all levels, FC West, EF-HR and TK (both levels), excluding the products (chips and fragments) generated spontaneously.

B) Lien Test (Lagarde 1983) showing the contribution of each raw material to the different categories of objects.

Figure 18 - A) Nombre total et matières premières des matériaux de percussion actifs et passifs dans la séquence analysée d'Olduvai (DK, FLK Zinj, FLK North tous niveaux, FC West, EF-HR et les deux niveaux de TK), à l'exclusion des produits (esquilles et fragments) générés spontanément.

B) Test de Lien (Lagarde 1983) montrant la contribution de chaque matière première aux différentes catégories d'objets.

Focusing on more specific issues, it seems that Olduvai hominids used lavas and quartzes simultaneously as raw materials for their percussion activities. Although there is a gradual increase of the frequency of quartz battered tools (fig. 17), this is a common pattern among all lithic categories in Bed II, and is therefore not exclusive to the items involved in percussion activities (i.e. Kyara 1999). Concerning the breakdown by raw materials, there is general preference for lavas as knapping hammerstones (Figure 18a). Anvils seem to be closely linked to the availability of quartz (fig. 18b), particularly those with tabular shapes; these forms facilitate stability of blocks on the ground, and could be an indicator of raw material selectivity, as documented in the chert and basalt anvils in Ubeidiya, chosen by their flat platforms (Bar-Yosef \& Goren-Inbar 1993).
Percentages of tool types throughout the Beds I and II sequence show interesting patterns. Knapping hammerstones are always the most abundant pounding artefacts (fig. 19): In EF-HR, $100 \%$ of the percussion artefacts are classic hammerstones, and in DK these objects are $97.1 \%$ of the total, with a very similar pattern to FLK Zinj (90\%). Other assemblages show lower percentages of classic hammerstones, like FC West $(72.1 \%)$ and FLK North I (Levels 6-1) (63.2\%), whilst at TK (both levels) they drop to $54.4 \%$, and at FLK North II (Deinotherium Level and Sandy Conglomerate Level), the rate of classic hammerstones decreases to $40.4 \%$.

Figure 19 also shows that in Middle-Upper Bed II, except for EF-HR, different modalities of battering items accompany classic hammerstones. As aforementioned, Willoughby

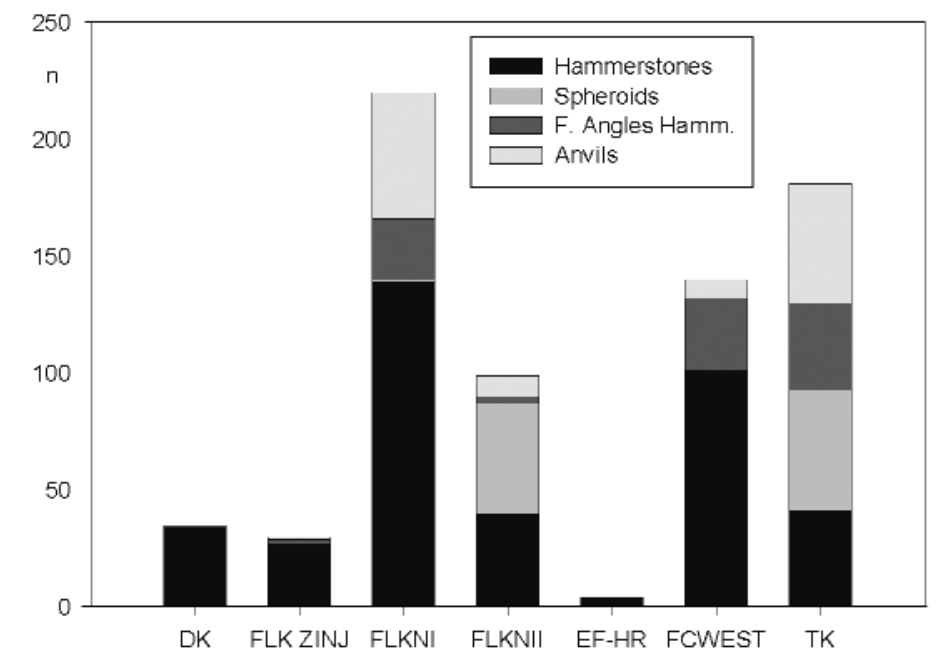

Figure 19 - Absolute frequencies of the different pounded pieces categories in each of the analysed sites.

Figure 19 - Fréquences absolues des différentes catégories de pièces percutées pour chaque site analysé. 


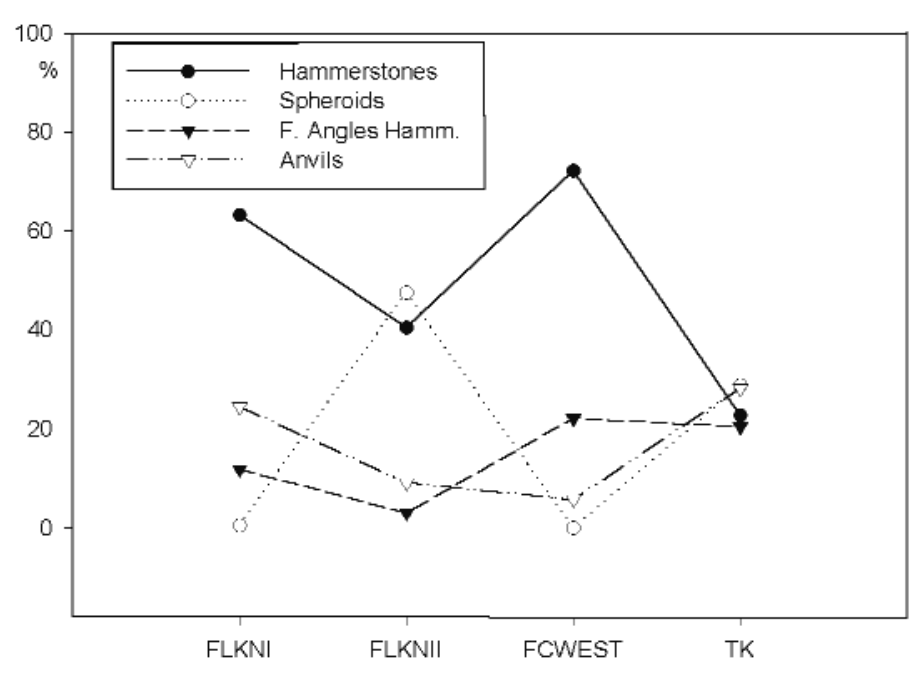

Figure 20 - Relative frequencies of the different percussion categories in the sites with the greatest variety of pounded pieces.

Figure 20 - Fréquences relatives des différentes catégories de percussion pour les sites avec la plus grande variété de pièces percutées.

(1987) and Texier \& Roche (1995) suggest a functional association between spheroids and anvils. Unfortunately, our results are not very enlightening in this respect: although at FC West and TK there is a co-variation in both categories of items (fig. 20), at FLK North II (Deinotherium and Sandy Conglomerate Levels) -where spheroids are the most abundant category (47.5\%) - anvils are scarce $(9.1 \%)$.

Relative frequencies show a negative correlation between classic hammerstones and spheroids (see fig. 20). For example, the percentage of spheroids at FLK North I (Levels 6-1) is practically nonexistent $(0.5 \%)$, whilst there is a $63.2 \%$ of classic hammerstones. The same pattern occurs at FC West, with $72.1 \%$ knapping hammerstones but not a single spheroid. The opposite occurs at FLK North II and TK, where classic hammerstones attain their lowest frequencies and spheroids appear in the highest percentages ( $47.5 \%$ and $28.7 \%$ respectively). This inverse correlation between two tool types created by archaeolo- gists could only be masking reality, i.e. that both spheroids and classic hammerstones belong to one single group. Other quantitative tests (i.e. fig. 21) support this suggestion, since there is an overlapping of hammerstone and spheroid sizes. Figure 22a is also significant, because there is a similar distribution as regards the average weight of spheroids and hammerstones. Thus, on the basis of the recounts of items and quantitative analyses, it might be suggested that Olduvai spheroids were being used for the same function as classic hammerstones (i.e. knapping activities), as pointed out by experimental studies (i.e. Schick \& Toth 1994; Sahnouni et al. 1997).

Figure $22 a$ shows that hammerstones with fracture angles have a similar weight to classic hammerstones and spheroids. Figure $22 \mathrm{~b}$ denotes an identical co-variation in the mean size of classic hammerstones and hammerstones with fracture angles. This pattern suggests the continuity of a process that most likely would begin with

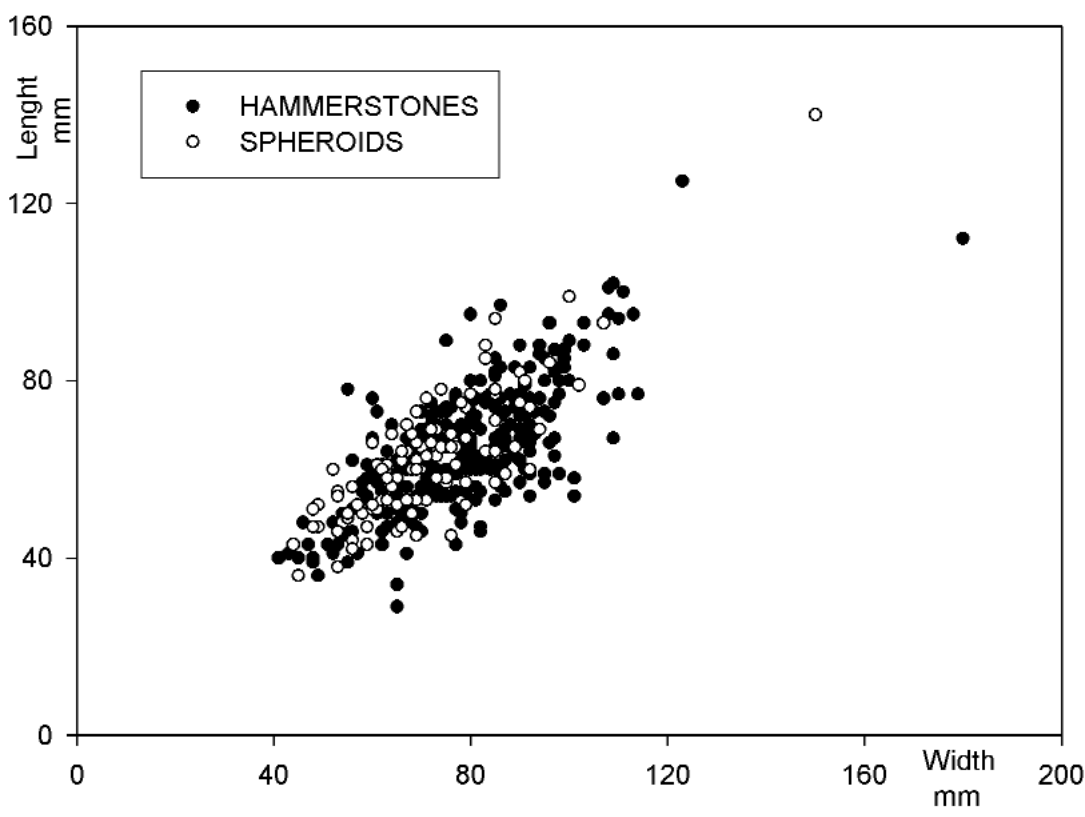

Figure 21 - Length and width of classic hammerstones and spheroids in different stages of transformation.

Figure 21 - Longueur et largeur des percuteurs classiques et des sphéroïdes à différents stades de transformation. 


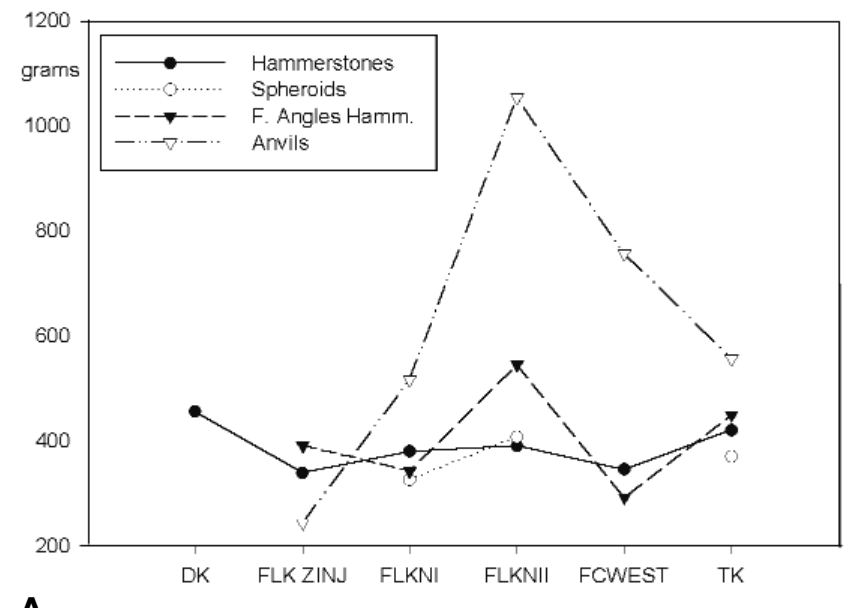

A

Figure 22 - A) Mean weight of the different categories in several of the sites. EF-HR excluded given the low number of items. B) Mean length of the different categories in some of the analysed sites.

Figure 22 - A) Masse moyenne des différentes catégories dans plusieurs sites (à l'exclusion de EF-HR compte tenu du petit nombre de pièces). B) Longueur moyenne des différentes catégories dans certains des sites analysés.

the use of cobbles as knapping hammerstones which when they started to break and therefore became unsuitable for detaching flakes- were recycled for complementary activities. Quantitative analyses do not help to distinguish tool types, since hammerstones with fracture angles were made on the same blanks as classic hammerstones, and therefore there are no size or raw material variations. Thus, the only feature differentiating both types of objects would be -if arguments set out above are accepted- that the battered ridges on hammerstones with fracture angles are not suitable for knapping, and therefore their function should have been different.

\section{CONCLUSIONS}

The Oldowan and African early Acheulean defined in Olduvai have always been considered as a paradigm to assess the technological skills of Plio-Pleistocene hominids. Nonetheless, such skills have been usually discussed by the assessment of knapping abilities, whereas systematic analysis of percussion tools in the Early Stone Age are not abundant (e.g. Chavaillon 1979; Mora \& de la Torre 2005; de la Torre \& Mora 2005). Others have stressed the importance of percussion activities in the earliest phases of human evolution (de Beaune 2004), and ethological studies (i.e. Boesch \& Boesch-Achermann 2000; Mercader et al. 2002, etc) have underlined the significance of percussion processes amongst chimpanzees and their similarities with the archaeological record.

Zooarchaeologists have highlighted the relevance of percussion processes carried out in the early archaeological sites (i.e. Binford 1984; Bunn 1989; Capaldo \& Blumenschine 1994; Blumenschine \& Selvaggio 1991;

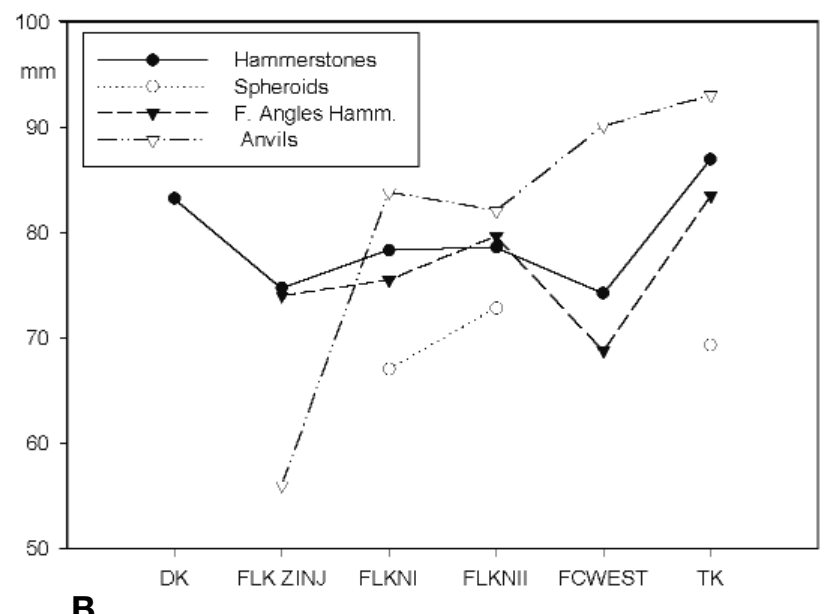


types on criteria such as the presence or absence of step and plunging fractures, pitting, battering, scars, bulbs, knapping platforms, shapes of dorsal and ventral sides, etc.

Problems raised with the categorisation of active percussion elements are a good example of such ambiguities. Figure 22a shows how active elements constitute a homogenous group, in which classic hammerstones, hammerstones with fracture angles, spheroids, and even anvils are not discrete morphotypes, but could be elements of the same chaine opératoire. This ambivalence of tool- type classification does not refer solely to active percussion elements; it has been documented that some cores were used previously as anvils. Furthermore, there are anvils that show battering characteristic of their use as active hammerstones. In addition, there are pieces with an even battering typical from knapping activities, which also show damaged ridges due to their sustained

In summary, Olduvai Beds I and II artefacts make up a dynamic sequence in which objects had a multi-faceted use and in which the morphotypes identified by archaeologists were interrelated with one another. In spite of this, we believe that, based on the stage of use in which the items were discarded, a distinction can be made between techno-morphological categories, and that such classification can help to discriminate tasks undertaken at each site. In assemblages such as TK or FLK North I, over 100 kilograms of raw material may have been used in percussion activities. In those and other assemblages such as FC West or FLK North II, percussive tasks could be the most significant technical activities, surpassing stone knapping. Following a previous work (Mora \& de la Torre 2005), our aim in this paper has been to stress the variability of activities undertaken by Olduvai hominids; they did not only use lithic material for knapping, they also invested a great amount of the stock of raw material in activities linked to the percussion of other elements, whichever these pounded elements were. Certainly, in Olduvai much was going on "entre le marteau et l enclume".

\section{Acknowledgements}

We thank Vincent Mourre and Marc Jarry for inviting us to the Table-Ronde "Entre le marteau et l enclume". We also thank the Governments of Kenya and Tanzania for their authorization to study the Olduvai collections. We appreciate comments made by Pierre Jean Texier, Dietrich Stout and Anne Delagnes to this paper. This work was funded by the Programa de Estancias Breves del Plan FPU of the Ministerio de Educación y Cultura (Spain) and the Estades per a la Recerca a Fora de Catalunya 2001 (BEAI400198) of the Generalitat de Catalunya.

\section{BIBLIOGRAPHY}

ALIMEN M.-H. 1963 - Enclumes (percuteurs dormants) associées à I Acheuléen supérieur de I Ougartien. Bulletin de la Societé Préhistorique Française, LX, p. 43-47.
ASHTON N., MCNABB J., PARFITT S. 1992 - Choppers and the Clactonian: A Reinvestigation. Proceedings of the Prehistoric Society, 58, p. 21-28.

BAR-YOSEF O., GOREN-INBAR N. 1993 - The Lithic Assemblages of Ubeidiya. A Lower Palaeolithic Site in the Jordan Valley. Jerusalem: Quedem, Monographs of the Institute of Archaeology $n^{\circ} 34$.

BINFORD L. R. 1984 - Faunal Remains from Klasies River Mouth. Orlando: Academic Press.

BINGHAM P. M. 2000 - Human Evolution and Human History: A Complete Theory. Evolutionary Anthropology, 9, p. 248-57.

BLUMENSCHINE R. J. 1986 - Early hominid scavenging opportunities: implications of carcass availability in the Serengeti and Ngorongoro ecosystems. Oxford: BAR International Series 283.

BLUMENSCHINE R. J. 1995 - Percussion marks, tooth marks, and experimental determinations of the timing of hominid and carnivore access to long bones at FLK Zinjanthropus, Olduvai Gorge, Tanzania. Journal of Human Evolution, 29, p. 21-51.

BLUMENSCHINE R. J., MAREAN C. W., CAPALDO S. D. 1996 - Blind Tests of Inter-analyst Correspondence and Accuracy in the Identification of Cut Marks, Percussion Marks, an Carnivore Tooth Marks on Bone Surfaces. Journal of Archaeological Science, 1996, p. 493-507.

BLUMENSCHINE R. J., SELVAGGIO M. M. 1991 - On the marks of marrow bone processing by hammerstones and hyenas: Their anatomical patterning and archaeological implications. In J. D. Clark (Ed.), Cultural beginnings: approaches to understanding early hominid lifeways in the African savannah. Mainz, Romisch-Germanisches Zentralmuseum, p. 17-32.

BOESCH C., BOESCH H. 1983 - Optimization of nutcracking with natural hammers by wild chimpanzees. Behaviour, 83, p. 265-286.

BOESCH C., BOESCH H. 1993 - Diversity of tool use and tool-making in wild chimpanzees. In A. Berthelet et J. Chavaillon (Eds.), The Use of Tools by Human and Nonhuman Primates. Oxford, Clarendon Press, p. 158-168.

BOESCH C., BOESCH-ACHERMANN H. 2000 - The Chimpanzees of the Taï Forest. Behavioural Ecology and Evolution. Oxford: Oxford University Press.

BRACCO J.-P. 1993 - Mise en évidence d une technique spécifique pour le débitage du quartz dans le gisement badegoulien de la Roche à Tavernat (Massif Central, France). Préhistoire Anthropologie Méditerranéennes, 2, p. 43-50.

BUNN H. T. 1982 - Meat-Eating and Human Evolution: Studies on the Diet and Subsistence Patterns of Plio- 
Pleistocene Hominids in East Africa. Berkeley: University of California. Unpublished Ph.D.

BUNN H. T. 1986 - Patterns of Skeletal Representation and Hominid Subsistence Activities at Olduvai Gorge, Tanzania, and Koobi Fora, Kenya. Journal of Human Evolution, 15, p. 673-690.

BUNN H. T. 1989 - Diagnosing Plio-Pleistocene Hominid Activity with Bone Fracture Evidence. In R. Bonnichsen et M. H. Sorg (Eds.), Bone modification. Orono, Center for the Study of the First Americans, p. 299-315.

CALVIN W. H. 2002 - A brain for all seasons: Human evolution \& abrupt climate change. Chicago: University of Chicago Press.

CAPALDO S. D., BLUMENSCHINE R. J. 1994 - A quantitative diagnosis of notches made by hammerstone percussion and carnivore gnawing on bovid long bones. American Antiquity, 59, p. 724-748.

CHAVAILLON J. 1976 - Evidence for the Technical Practices of Early Pleistocene Hominids, Shungura Formation, Lower Omo Valley, Ethiopia. In Y. Coppens, F. C. Howell, G. L. Isaac et R. E. F. Leakey (Eds.), Earliest Man and Environments in the Lake Rudolf Basin. Chicago, University of Chicago Press, p. 565-573.

CHAVAILLON J. 1979 - Essai pour une typologie du matériel de percussion. Bulletin de la Societé Préhistorique Française, 76, p. 230-233.

CHAVAILLON J., CHAVAILLON N. 1976 - Le Paléolithique ancien en Ethiopie. Caractères techniques de I Oldowayen de Gomboré I a Melka-Konturé. In J. D. Clark et G. L. Isaac (Eds.), Colloque V: Les plus anciennes industries en Afrique. Nice, UISPP IX Congrés, p. 43-69.

CHAVAILLON J., CHAVAILLON N. 1981 - Galets aménagés et nucleus du Paléolithique Inférieur. In C. Roubet, H.-J. Hugot et G. Souville (Eds.), Préhistoire Africaine, Mélanges au Doyen Lionel Balout. Paris, ADPF, p. 283-292.

CHAVAILLON J., PIPERNO, M. (Eds.) 2004 - Studies on the Early Paleolithic site of Melka Kunture, Ethiopia. Florence: Istituto Italiano di Preistoria e Protostoria.

CLARK J. D. 1955 - The stone ball: its associations and use by prehistoric man in Africa. In L. Balout (Ed.), II Congrès Panafricain de Préhistoire, Alger. Actes de la lle session. Paris, Arts et Métieres graphiqies, p. 403-417.

CLARK J. D., KLEINDIENST M. R. 1974 - The Stone Age cultural sequence: terminology, typology, and raw material. In J. D. Clark (Ed.), Kalambo Falls Prehistoric Site, Vol 2. Cambridge, Cambridge University Press, p. 71-106.

CLARK J. D., KLEINDIENST M. R. 2001 - The Stone Age cultural sequence: terminology, typology and raw material. In J. D. Clark (Ed.), Kalambo Falls Prehistoric Site, Vol III:
The Earlier Cultures: Middle and Earlier Stone Age. Cambridge, Cambridge University Press, p. 34-65.

de BEAUNE S. 2004 - The Invention of Technology: Prehistory and Cognition. Current Anthropology, 45, p. 139-162.

DELAGNES A., ROCHE H. 2005 - Late Pliocene hominid knapping skills: The case of Lokalalei $2 \mathrm{C}$, West Turkana, Kenya. Journal of Human Evolution 48, p. $435-472$.

GOREN-INBAR N., SHARON G., MELAMED Y., KISLEV M. E. 2002 - Nuts, nut cracking, and pitted stones at Gesher Benot Ya aqov, Israel. PNAS, 99, p. 2455-2460.

HARRIS J. W. K., WILLIAMSON P., VERNIERS J., TAPPEN M., STEWART K., HELGREN D., DE HEINZELIN J., BOAZ N., BELLOMO R. 1987 - Late Pliocene hominid occupation in Central Africa: the setting, context, and character of the Senga 5A site, Zaire. Journal of Human Evolution, 16, p. 701-728.

INIZAN M.-L., REDURON-BALLINER M., ROCHE H., TIXIER J. 1995 - Technologie de la pierre taillée. Meudon: CREP.

ISAAC B. 1987 - Throwing and human evolution. The African Archaeological Review, 5, p. 3-17.

ISAAC G. L. 1986 - Foundation stones: early artifacts as indicators of activities and abilities. In G. N. Bailey et P. Callow (Eds.), Stone Age Prehistory: studies in Memory of Charles McBurney. Cambridge, Cambridge University Press, p. 221-241.

ISAAC G. L., HARRIS J. W. K., KROLL E. M. 1997 - The Stone Artefact Assemblages: A Comparative Study. In G. L. Isaac (Ed.), Koobi Fora Research Project. Volume 5: PlioPleistocene Archaeology. Oxford, Oxford University Press, p. 262-362.

JONES P. R. 1994 - Results of experimental work in relation to the stone industries of Olduvai Gorge. In M. D. Leakey et D. A. Roe (Eds.), Olduvai Gorge. Volume 5. Excavations in Beds III, IV and the Masek Beds, 1968-1971. Cambridge, Cambridge University Press, p. 254-298.

KIMURA Y. 1999 - Tool-using strategies by early hominids at Bed II, Olduvai Gorge, Tanzania. Journal of Human Evolution, 37, p. 807-831.

KIMURA Y. 2002 - Examining time trends in the Oldowan technology at Beds I and II, Olduvai Gorge. Journal of Human Evolution, 43, p. 291-321.

KLEINDIENST M. R. 1962 - Component of the East African acheulian assemblage: an analytic approach. In G. Mortelmans et J. Nenquin (Eds.), Actes du IV Congrès Panafricain de Préhistoire et de l'Etude du Quaternaire, Leopoldville, 1959. Tervuren, Belgie Annalen, Musée Royal de l'Afrique Centrale, p. 81-108. 
KLEINDIENST M. R., KELLER C. M. 1976 - Towards a functional analysis of handaxes and cleavers: the evidence from Eastern Africa. Man, 11, p. 176-187.

KNIGHT J. 1991 - Vein Quartz. Lithics, 12, p. 37-56.

KUMAN K. 1998 - The earliest South African industries. In M. D. Petraglia et R. Korisettar (Eds.), Early Human Behavior in Global Context. Rise and Diversity of the Lower Paleolithic Record. London, Routledge, p. 151-186.

KYARA O. A. 1999 - Lithic Raw Materials and Their Implications on Assemblage Variation and Hominid Behavior During Bed II, Olduvai Gorge, Tanzania. New Brunswick: University of Rutgers. Unpublished Ph.D.

LAGARDE J. 1983. Initiation à I analyse des données. Paris : Dunod.

LE BRUN-RICALENS F. 1989 - Contribution à l étude des pièces esquillées: la présence de percuteurs à «cupules». Bulletin de la Societé Préhistorique Française, 86, p. 196-200.

LEAKEY M. D. 1971 - Olduvai Gorge. Vol 3. Excavations in Beds I and II, 1960-1963. Cambridge: Cambridge University Press.

LEAKEY M. D. 1975 - Cultural Patterns in the Olduvai Sequence. In K. W. Butzer et G. L. Isaac (Eds.), After the Australopithecines. Stratigraphy, Ecology, and Cultural Change in the Middle Pleistocene. Chicago, Mouton, p. 477-493.

LEAKEY M. D. 1979 - Olduvai Gorge: My Search for Early Man. London: Williams Collins Sons \& Co.

LEAKEY M. D., ROE D. A. 1994 - Olduvai Gorge. Volume 5. Excavations in Beds III, IV and the Masek Beds, 19681971. Cambridge: Cambridge University Press.

LUDWIG B. V. 1999 - A technological reassessment of East African Plio-Pleistocene lithic artifact assemblages. New Brunswick: University of Rutgers. Unpublished Ph.D.

MADRIGAL T. C., BLUMENSCHINE R. J. 2000 Preferential Processing of High Return Rate Marrow Bones by Oldowan Hominids: a Comment on Lupo. Journal of Archaeological Science, 27, p. 739-741.

MERCADER J., PANGER M. A., BOESCH C. 2002 Excavation of a Chimpanzee Stone Tool Site in the African Rainforest. Science, 296, p. 1452-1455.

MERRICK H. V. 1976 - Recent Archaeological Research in the Plio-Pleistocene Deposits of the Lower Omo, Southwestern Ethiopia. In : G. L. Isaac et E. R. McCown (Eds.), Human Origins. Louis Leakey and the East African Evidence. California, W.A. Benjamin, Inc., p. 461-481.

MORA R., de la TORRE I. 2005 - Percussion Tools in Olduvai Beds I \& II (Tanzania): Implications for Early Human Activities. Journal of Anthropological Archaeology, 24: 179-192.
MOURRE V. 1997 - Industries en quartz: Précisions terminologiques dans les domaines de la pétrographie et de la technologie. Préhistoire Anthropologie Méditerranéennes, 6, p. 201-210.

POTTS R. 1988 - Early Hominid Activities at Olduvai. New York: Aldine and Gruyter.

POTTS R. 1991 - Why the Oldowan? Plio-Pleistocene toolmaking and the transport of resources. Journal of Anthropological Research, 47, p. 153-176.

ROCHE H., TEXIER P.-J. 1996 - Evaluation of Technical Competence of Homo erectus in East Africa During the Middle Pleistocene. In J. R. F. Bower et S. Sartorno (Eds.), Human Evolution in its Ecological Context. Leiden, Royal Netherlands Academy of Arts and Sciences, p. 153-167.

SAHNOUNI M. 1991 - Étude comparative des galets taillés polyédriques, subsphériques et sphériques des gisements d Ain Hanech (Algérie Orientale) et d Olduvai (Tanzanie). L Anthropologie, 97, p. 51-68.

SAHNOUNI M. 1998 - The Lower Paleolithic of the Maghreb. Excavations and analyses at Ain Hanech, Algeria. Oxford: BAR International Series 689.

SAHNOUNI M., SCHICK K., TOTH N. 1997 - An Experimental Investigation into the Nature of Faceted Limestone «Spheroids» in the Early Palaeolithic. Journal of Archaeological Science, 24, p. 701-713.

SCHICK K. D., TOTH N. 1993 - Making Silent Stones Speak. Human Evolution and the Dawn of technology. London: Weindenfeld and Nicolson.

SCHICK K. D., TOTH N. 1994 - Early Stone Age Technology in Africa: a Review and Case Study into the Nature and Function of Spheroids and Subspheroids. In R. S. Corruchini et R. L. Ciochon (Eds.), Integrative Paths to the Past. Paleoanthropological Advances in Honor of F. Clark Howell. New Jersey, Prentice Hall, p. 429-449.

SHEN C., WANG S. 2000 - A preliminary study of the anvilchipping technique: experiments and evaluations. Lithic Technology, 25, p. 81-100.

SHIPMAN P. 1989 - Altered Bones from Olduvai Gorge, Tanzania: Techniques, Problems, and Implications of Their Recognition. In R. Bonnichsen et M. H. Sorg (Eds.), Bone modification. Orono, Center for the Study of the First Americans, p. 317-334.

TEXIER P.-J. 1996 - Evolution and diversity in flaking techniques and methods in the Palaeolithic. In Oltre la Pietra. Modelli e tecnologie per capire la Preistoria. Forli, UISPP XIII Congres, Abaco, p. 297-321.

TEXIER P.-J., ROCHE H. 1995 - Polyèdre, sub-sphéroïde, sphéroïde et bola: des segments plus ou moins longs d une même chaîne opératoire. Cahier Noir, 7, p. 31-40. 
TORRE I. DE LA, MORA R. 2005 - Technological strategies in the Lower Pleistocene at Olduvai Beds I \& II. Liège, ERAUL 112.

TOTH N. 1982 - The Stone Technologies of Early Hominids at Koobi Fora, Kenya; An Experimental Approach. Berkeley, University of California. Unpublished Ph.D.

TOTH N. 1985 - The Oldowan Reassessed: a Close Look at Early Stone Artifacts. Journal of Archaeological Science, 12, p. 101-120.
TOTH N. 2001 - Experiments in quarrying large flake blanks at Kalambo Falls. In J. D. Clark (Ed.), Kalambo Falls Prehistoric Site, III: The Earlier Cultures: Middle and Earlier Stone Age. Cambridge, Cambridge University Press, p. 600-604.

WILLOUGHBY P. R. 1987 - Spheroids and Batterd Stones in the African Early Stone Age. Oxford: BAR International Series 321.

WYNN T. 1989 - The Evolution of Spatial Competence. Illinois: University of Illinois Press. 